\title{
An Appraisal of The Effect of Visual Discrimination Training in the Recognition of Pictures on Reading Among Struggling Readers in Primary Schools in Buea Municipality Cameroon
}

\author{
Yolle Mukete Jeannette \\ B.Ed. (Hons), M.Ed, PhD, \\ University of Buea, Buea, Cameroon
}

\begin{abstract}
The realisation of the full potentials of all learners has been and is the utmost concern of Special Education and Educators. This study was out to carry out $\mathrm{S}$ an appraisal of the effect of visual discrimination training in the recognition of pictures on reading among struggling readers in primary schools in the Buea municipality Cameroon.
\end{abstract}

It made use of three primary schools (government, mission and private) in a quasi-experimental study. Twenty-four struggling readers were used to verify if visual discrimination training on word recognition has any effect on their reading ability. They were selected sequentially through teacher nomination, classroom records and a standard oral reading test. The 24 most severe cases were subjected to ballot to distribute them into two groups (experimental and control). Each group had 12 participants including boys and girls between the ages of $10-11$ years. The pre-testpost-test techniques were used to measure the progress made by each group within a period of 8 weeks. Only the experimental group received the treatment exercise. The instruments used for data collection were a master sheet for reading assessment, test score sheet produce by the researcher, an interview guide for pupils and their teachers. Data were analysed using the statistical package SPSS 21.0. They were analyzed and presented descriptively using frequencies, percentages, tables and charts, while hypotheses were tested using the Chi-Square test of equality of proportions comparing the aggregated scores of the experimental and control group. Interviews were analysed using the thematic and case approach, and summarized in codegrounding-quotation tables and conceptual diagram. Results revealed that there was a significant positive progression in the experimental group. The progression for picture images was the $37.5 \%$ as against $10.0 \%$ for the control group. Thus, the null hypotheses were rejected while the alternative was retained. This implies that visual discrimination training has a positive effect on reading among struggling readers. This knowledge will lead to improvement in pedagogic practices in primary schools. The study therefore recommends that visual discrimination training be introduced as earlier as possible, and reinforced in all classes in primary schools to give all children the possibility to improve.

KEY WORDS: Appraisal, Visual, Discrimination, Training, Recognition, Pictures, Reading, Struggling, Readers, Primary Schools, Buea

\section{INTRODUCTION}

Reading is an important component of the school curriculum, which determines the extent to which learners achieve academic competence and develop a positive self-esteem. It is a left brain activity which is often difficult to the right brain dominant learner.

Visual discrimination training is an intervention technique used in teaching to enable struggling readers recognises similarities and differences in print. Struggling readers are unable to read their notes and other age appropriate literature. This affects their academic achievements with negative consequences on their families the educational system and the larger community. Primary five pupils ought to read to cope with the workload in public examination the following year. Children in any given classroom come from different backgrounds with varied strengths, weaknesses and aspirations based on their exposure 
and hereditary factors. Some before schooling have been exposed to books with reading models at home .Others receive assistance with their school work from home teachers, parents and siblings who reinforce what was taught in school. While others who come from poor and underprivileged background, including hereditary factors rely solely on the school to provide them with the necessary support to enable them to read. Literature reveals that some struggling readers could be very intelligent but experience difficulties with reading requiring remedial instruction to be able to read. Teachers through training ought to understand their pupils, their characteristics, their socio cultural environment and the nature of reading to be able to help children with disabilities (struggling readers) in their classrooms and schools. They ought to be able to identify learners by their strengths and weaknesses and then focus on their strength to help them develop skills and eventually their full potentials for a healthy personality. Several efforts have been made by the educational system to adjust pedagogy practices to bridge the gap between proficient and struggling readers in Cameroon yet some children graduate or drop out from school without being able to read. My assumption is that more struggling readers will be able to read by primary five if provided with early and appropriate differentiated instruction. The purpose of this study is to investigate if visual discrimination training on the recognition of items has any effect on reading among struggling readers in primary five in the Buea municipality in Cameroon. This chapter is focuses on the background to the study, the statement of the problem, the purpose of the study and research questions. The research hypothesis, significance of the study, the scope of the study and definition of terms were also examined.

\section{Statement of the Problem}

This study was out to carry out an appraisal of the effect of visual discrimination training in the recognition of pictures on reading among struggling readers in primary schools in the Buea municipality Cameroon. Field observation reveals that struggling readers in primary five are often excluded in the learning to read process because their reading attempts were fraught with frequent stops and starts, with errors of omission, substitution, reversals and repetition. Struggling readers are often labelled as dull, stupid, lazy, slow learners and good for nothing children, though they may be very intelligent but experience difficulties with reading. This has negative consequences on the learners their family the educational family and the larger community. The few pupils who could read are often asked to read without any effort to motivate struggling readers to read. The classroom environment on their part is often not literacy friendly to help motivate those from poor and underprivileged home background to have materials to read.

Several literatures exist in Cameroon stating the different methods that could be used in teaching children how to read yet some children keep struggling with reading. To the best of my knowledge, no literature exists in Cameroon on how to assess struggling readers to determine why they struggle with reading before providing the remedial instructions. This study may give direction to the quality of instruction that is required to help struggling readers read. It is against this backdrop that this study sought to investigate the effect of visual discrimination training on reading among struggling readers in primary five.

\section{Objective}

To find out the effect of visual discrimination training in picture recognition on reading among struggling readers in primary school in Buea municipality in Cameroon.

\section{Research Question}

What is the Effect of visual discrimination training in picture recognition on reading among struggling readers in primary five?

\section{Research Hypothesis}

Ho: There is no impact on reading because of visual discrimination training in the recognition of pictures among struggling readers in primary five.

\section{Ha: There is an impact on reading because of visual discrimination training in the recognition of picture among struggling readers in primary five}

\section{Justification of the study}

Basic Education authorities are currently seeking ways to improve upon the reading performance of primary school pupils in Cameroon. As reported by the World Bank report (2014) on the quality of basic education in Cameroon. This is challenging especially with the new trend of teaching to meet the specific needs of learners with disabilities in inclusive classrooms. The present study was designed to determine the effect of visual 
discrimination training in the recognition of items on reading among struggling readers in primary five in the Buea municipality Cameroon. The knowledge and information obtained will help to improve on the attitude and practices of the following groups of people:

\section{$>$ Head Teachers:}

Head teachers will see the need for selecting competent teachers as level heads or pedagogic animators who will be charged with the responsibility to assess and plan remediation lessons for struggling readers within the classes at their levels.

$>$ Besides, they will see the need to resume their pedagogic role in school to reinforce the organization of remediation lessons in the schools and to help struggling readers to become proficient readers with time.

$>$ In addition, they will ensure that classroom environments are literacy friendly to nurture literacy in the children irrespective of their home background.

\section{$>$ Teachers}

Teachers will see the need to practice the pedagogy of inclusion in their classrooms so that they can give all the learners equal opportunity to learn.

$>$ Besides, they will endeavour to improve their classroom environment with wall cards, picture cards, labels, ward walls, charts and other necessary materials to nurture the reading culture in the children.

\section{$>$ Parents}

Parents will see the need to change their attitude towards collaborating with the school by honouring their invitation when their attention sought and during Parent Teacher Association meeting.

$>$ Besides, they will see the need to take up their responsibility to provide their children with the basic school needs and make provision for helping them with their schoolwork at home.

\section{$>$ Pedagogic Inspectors}

They will see the need to monitor and supervise reading instruction in schools and then to guide the teachers on the strategies they could use to help learners to improve upon their reading performance in primary school.
Policy Makers: Policy makers will see the need to enrich the training programs of teachers to suit the inclusive nature of our classrooms so that the teachers will be able to handle large and complex classrooms for the interest of all learners.

\section{BACKGROUND}

Visual discrimination of picture images is the ability to use visual stimuli to discriminate similarities and differences in pictures. According to Thibault and Walbert (2007), picture books offer a unique opportunity for children to develop visual literacy as they return to the visual images in books to explore, reflect and criticize those images. She argues that when this happens, children are able to develop deeper meaning from literature and an awareness of how visual images are used in meaning making. And that through guidance, children learn that illustration can be seen in different ways.

She stresses that through picture images, children walk through a text to prepare their minds for what is in the text. She reiterates that teachers should help children to work through pictures by asking questions that will help them focus on details in the pictures in order to understand better. Pupils should be asked about what they see, what is happening in the illustration and the role of various elements like colour, light, perspective and placement of objects that help to indicate the story. They argue that this will help the children draw background information or experiences as they interpret the illustrations.

To Matlin(1988), Prinzand Meltal(1995), as in Burns et al(1996), to be able to discriminate picture images, the eyes and the brain must be able to organise the usual sensation. They stress that the effect of visual figure ground on the picture images causes one to see more of what is going on in one's mind than what is in front of the eye. And that the eye tends to see continuity of perceived lines and patterns that follow a smooth pattern as part of a single unit. They argue that proximity affects picture images in that pictures that are closed together are usually perceived as belonging together while things that are similar are perceived to be related. They contend that incomplete images of the face tend to be perceived as complete whole when they are closed.

This implies that perceiving picture images will depend on its figure ground, proximity, similarities, nearness and continuity. The practical implication 
here is that teachers should understand these principles of perception of pictures, before presenting pictures to the children for discussion. This will enable them better appreciate the varied interpretations of pictures by children.

To Renee (2013), presenting pictures to children should be followed by questions to draw their attention to peculiarities that may not be noticed by them. This will force them to observe differences and peculiarities in pictures. She stresses that when such questions are focused on visual characteristics, they give children the opportunity to observe different pictures and gradually begin to gain confidence in observing different pictures on their own. She emphasizes that to help children to develop visual discrimination skills for pictures, their attention should be drawn to the colours of the pictures, the words that spell the pictures and to note the letters that make up the words. They argue that their attention should also be drawn to the beginning letters of the words as these will be the strong clues to reading the words.

According to Schools Sparks (2013), most of all information in school is introduced by demonstration in pictures or graphs. And that children may be expected to replicate these activities in their worksheets which requires visual discrimination skills. They stress that children may observe such demonstrations, but will be unable to replicate them on worksheets. They stress that this frustrates the children as they may be fooled into thinking that they are not good at sciences, whereas they may have a strong deficiency for visual discrimination skills. This implies that it is necessary to help the children to develop visual discrimination skills so that they can develop their potentials fully as they work through their environments

According to Renee (2013), visual discrimination is the ability to recognize details in visual images. It enables people to identify likenesses and differences between specific images. She stresses that, having strong visual discrimination skills enables children to observe details in their environment. She stresses that visual discrimination is important in the learning to read process in the following ways:

$>$ It enables children distinguish between various symbols that comprise the written language.

$>$ To recognize that words are groups of letters separated by space.
$>$ That letters are different from numerals

$>$ To learn names of letters (upper and lower cases)

$>$ That numbers range from $0-9$

$>$ To recognize distinct characters of each symbol

$>$ To recognize and remember differences around.

She emphasizes that to learn names of new friends and classmates, recognize people and object depends on visual discrimination skills. And that visual discrimination skill is important in many other school subjects of the curriculum. For example, in science experiments, demonstration in physical education, picture, discussion etc. Thus, it is the ability to use one's eyes to interpret accurately the surrounding stimuli in one's environment.

Hundt (2013), opines that visual discrimination is the ability to distinguish information on print. It is a tracking process which is associated with how the eyes transmit visual prints into the brain. He argues that children need visual discrimination skills to quickly see small visual details in things. He stresses that without these brain skills, children may not be able to see the similarities and differences in shape, colour, size, pattern, position and orientation. They argue that this will affect the way we understand and use similarities and differences in words, letters, shapes, pictures, and other objects. A deficit in this skill will make it very difficult for anyone to acquire literacy skills. He stresses that such deficit makes a child to appear immature for his or her age. And that such a child feels more comfortable with younger friends and children than they are. They emphasize that children with visual discrimination deficit have underdeveloped judgmental skills, as well as the inability to make good decisions.

To Gangwer (2010), visual discrimination is the ability to perceive words accurately noticing likenesses and differences in words, letters, numbers and other objects. He argues that visual discrimination deficits will cause learners to experience reversals, omissions and additions in their reading. This implies that reading becomes painful and stressful for struggling readers causing them to shy away from the experience.

Thus, children need visual discrimination skills to be able to read, which brings us to the need to understand the relationship between visual discrimination and reading. 
Visual discrimination is one of the visual processing disorders that affects the way images that pass through the eyes are transmitted to the brain. This has an effect on the learner's academic achievement. Learners with visual discrimination deficit experience difficulties that affect their performance in reading.

According to Arky (2014), visual discrimination deficits in learners result to the following experiences.

$>$ Confusion of similar letters and work

$>$ Letters and words reversals and inversions

$>$ Difficulties in following retaining visual sequences

$>$ Word substitutions

$>$ Distracted reading, skipping and jumping over works

$>$ Omission of words, phrases and sentences

$>$ Slow recognition of words

According to Arky (2014), visual discrimination deficit in children can be easily noticed when they begin school. He argues that this deficit affects the learners' academic, emotional and life skills. Academically, such children will have difficulties with reading, writing and mathematical. They may struggle with letters, numbers and symbols. Besides, they may have hard times remembering and recognizing what they read. He contends that emotionally, such learners may fall behind at school which affects their self-confidence and self-esteem. He reiterates that children with visual discrimination deficit will have difficulties with life skills which can make simple tasks; learning phone numbers, spelling, remembering names, matching socks difficult and stressful. He commends that intervention for such children should be early to avoid greater impact on a wide range of skills.

NCLD (2013), holds that visual discrimination is one of the visual disorders which involves using the sense of sight to notice and compare features of different items to distinguish one item from another. They argue that learners with visual discrimination difficulties experience difficulties seeing the differences between two similar letters, shapes, numbers or other objects. They stress that such learners also have difficulties noticing the similarities and differences between certain colours, shapes and patterns. They emphasize that to help learners with visual discrimination deficit, reading instruction provided to them must clearly space words or problems on a page. Also, the teacher should anticipate the confusion and point out examples of correct responses to draw their attention to what is required. In the same light, Kurtz and Netlibrary (2006) as cited in Clutten (2009) contest that learners with visual discrimination deficit experience difficulties learning the alphabet and recognizing words and letters. They stress that such learners will easily confuse similar shapes, letters, words, numbers and also experience regular reversals with words with similar beginnings and endings. They argue that such learners will have difficulties writing and remembering letters and that they turn to use other senses (tactile and verbal) to make sense of what is visual. They recommend that classroom instruction should involve sorting and games (spot the differences) that will draw their attention to their areas of difficulties.

This view is supported by Snow Burns and Griffin (1998) as cited by Reading Rocket(2011) that to effectively teach reading, teachers need to have a strong and deep understanding for reading theories and practices. They need to be able to pinpoint the nature and source of a student's difficulty by increasing skill levels and building upon the strength of the learner rather than labelling and excluding them in the learning to read process. This implies that to effectively teach struggling readers to read, parents and teachers should endeavour to identify why the pupil struggles with reading in order to be able to provide the appropriate instruction that will meet their needs.

\section{METHODOLOGY}

The research design used for this study is the experimental design. Specifically the quasiexperimental type of double group pre-test and posttests sub-type, the experimental group was consist of four participants per school who were taught for eight weeks using the participatory approach. This approach was adopted because it enabled the researcher to work with the participants in a natural classroom environment in various actives using item cards, and taking part in practical exercises and assignments. The control group was consist of four participants per school who did not receive any intervention but continued their normal session with their class teacher. The quasi-experimental design was seen as the appropriate design because the study sought to establish the relationship that exist between the dependent and independent variable 
According to Amin (2005), experimental research allows the researcher to study variables that could not ethically be manipulated by the experimenter. In this light, the researcher was able to conduct interviews with the participants and their teachers. Shuttle worth (2008), Fraenkel and Wallen (2006), and Cohen, Monion and Morrison(2007) contend that in quasiexperimental design participants are not allocated at random, but selected judgemental. This permitted the researcher together with the class teacher to nominate struggling readers in their respective classrooms. Participants were sampled through multiple stage sampling to ensure that they met the criterion for selection. They argue that quasi-experimental studies operate in a natural setting, which permits the extraneous variables that could affect the results to be controlled to reduce threads to internal validity. In this light, the researcher imposed a criterion for selection requiring that the participants must be in class must be struggling readers, must be aged 9-11 years and could be male or female.

The nominees were subjected through an oral reading test to ascertain if they were struggling readers before subjecting them to a pre-test. This was at the commencement of the experiment and a post-test after the treatment exercise that was administers only to the experimental group. This was so to enable the researcher to be able to make inferences at the end of the experiment. Both groups were tested at the same time, at the beginning of the experiment (pre-test) and at the end of the treatment period (post-test) using the same instrument and by the researcher. They were followed- up over the same duration before the post evaluation. Data were collected directly from the participants for 10 weeks from the $18^{\text {th }}$ of April to the $5^{\text {th }}$ of June 2015. One week was for the selection period that included teachers' nomination, examination of class records and the standard test. The intervention period covered 8 weeks from the pre-test to the post test. The pupils and the teachers were interviewed as to have more information on the challenges they face with respect to reading over the remaining one week.

\section{AREA OF THE STUDY}

This study was carried out in Buea municipality in Fako Division of the South West Region of Cameroon. It is one of the sub-divisions within Fako division. This is a cosmopolitan town located at the foot of Mount Fako with 156 primary schools dispersed in the municipality. It harbours a population with varied cultural and socioeconomic background. The people are involved in all works of life. The settlement areas are carved in a triangular form accessed by road. According to(Nana, 2015; Shadish, Cook and Campbell 2000; Trochim, 2006) experimental study did not permit asimple random sampling of participants throughout the study. It requiresa well-demarcated geographical area purposively selected based on the nature of the study. In line with this view, three schools with three different backgrounds were selected purposefully within Buea municipality. That is, Government school Bonduma group1, C. B. C. Bolifamba mile and Bonandive academic centre Woniamavio. These schools were widely dispersed to ensure that children from different background were included in the study.

\section{POPULATION OF THE STUDY}

This study is focused on struggling readers in primary five in Buea municipality. According to Fraenkel and Wallen (2007), the population of interest in a study is a group of people who possess certain characteristics. The target population for this study was all primary five pupils who are struggling with reading. These schools included all government schools, all mission schools and all lay private schools within Buea municipality, while the accessible population was the three schools from where the sample was drawn. That is, Government school Bunduma group1, Cameroon Baptist Convention Boli famba mile 16 and Bonandive Academic centre Woniamavio. They were chosen through the simple random sampling method based on their categoryso as to give all the schools an equal opportunity to participate in the study. 
Table 1: Summary statistics for primary schools on enrolment sex and class 2014/2015.

\begin{tabular}{|c|c|c|c|c|c|c|c|c|c|c|c|c|c|c|c|c|c|c|c|c|c|c|}
\hline SN & $\begin{array}{l}\text { School } \\
\text { types }\end{array}$ & $\begin{array}{l}\text { Clas } \\
\mathrm{s} 1\end{array}$ & $\begin{array}{l}\text { Clas } \\
52 \\
\end{array}$ & $\begin{array}{l}\text { Clas } \\
\text { s } 3 \\
\end{array}$ & $\begin{array}{l}\text { Clas } \\
\text { s } 4 \\
\end{array}$ & $\begin{array}{l}\text { Clas } \\
\text { s } 5 \\
\end{array}$ & $\begin{array}{l}\text { Clas } \\
\text { s } 6 \\
\end{array}$ & Tota & & & & & & & & & & & & & & \\
\hline 1 & $\begin{array}{l}\text { Governme } \\
\text { nt }\end{array}$ & 325 & 319 & 644 & 303 & 338 & 641 & 359 & 363 & 723 & 433 & 403 & 846 & 522 & 426 & 9552 & 383 & 351 & & $\begin{array}{l}236 \\
0\end{array}$ & 2200 & $\begin{array}{l}1314 \\
0\end{array}$ \\
\hline 2 & Catholic & 202 & 197 & 399 & 219 & 246 & 465 & 251 & 252 & 503 & 274 & 264 & 538 & 293 & 314 & 6077 & 249 & 276 & 525 & $\begin{array}{l}151 \\
5\end{array}$ & 1549 & 8507 \\
\hline 3 & Baptist & 49 & 47 & 96 & 49 & 37 & 86 & 54 & 43 & 97 & 54 & 46 & 100 & 60 & 47 & 1077 & 55 & 44 & 99 & 309 & 264 & 1555 \\
\hline 4 & $\begin{array}{l}\text { Presbyteria } \\
n\end{array}$ & & 43 & 105 & 62 & 74 & 136 & 51 & 77 & 128 & 47 & 56 & 103 & 77 & 79 & 1566 & 49 & 69 & 118 & 360 & 398 & 2156 \\
\hline 5 & $\begin{array}{l}\text { Anglo } \\
\text { Arabic }\end{array}$ & 6 & 9 & 15 & 6 & 7 & 13 & 4 & 5 & 9 & 4 & 6 & 10 & 6 & 5 & 111 & 5 & 2 & 7 & 32 & 34 & 165 \\
\hline 6 & $\begin{array}{l}\text { Lay } \\
\text { private }\end{array}$ & 944 & 894 & 1881 & 840 & 924 & 1754 & 833 & 900 & $\begin{array}{l}173 \\
3 \\
\end{array}$ & 808 & 806 & $\begin{array}{l}161 \\
7 \\
\end{array}$ & 740 & 752 & $\begin{array}{l}1480 \\
0\end{array}$ & 674 & 605 & $\begin{array}{l}127 \\
9\end{array}$ & $\begin{array}{l}492 \\
3 \\
\end{array}$ & 4881 & $\begin{array}{l}2306 \\
4\end{array}$ \\
\hline Tota & 1588 & 1509 & 3140 & 1479 & 1626 & 3095 & 1552 & 1640 & $\begin{array}{l}319 \\
3 \\
\end{array}$ & $\begin{array}{l}162 \\
0 \\
\end{array}$ & $\begin{array}{l}158 \\
1 \\
\end{array}$ & $\begin{array}{l}321 \\
4 \\
\end{array}$ & \begin{tabular}{|l|}
169 \\
8
\end{tabular} & $\begin{array}{l}162 \\
3 \\
\end{array}$ & $\begin{array}{l}3318 \\
3\end{array}$ & 1415 & $\begin{array}{l}134 \\
7 \\
\end{array}$ & $\begin{array}{l}276 \\
2\end{array}$ & $\begin{array}{l}949 \\
9 \\
\end{array}$ & $\begin{array}{l}932 \\
6 \\
\end{array}$ & $\begin{array}{l}4858 \\
7 \\
\end{array}$ & \\
\hline
\end{tabular}

Source: Inspectorate of Basic education-Buea.

\section{Sample Size}

The non-probability sampling method was used to select the sample. This is a method where some elements of the population have no chance of being selected. The samples were selected based on the assumption that they will provide the necessary data for the study. Fraenkel and Wallen (2006) and Cohen, Moion and Morrison (2007)

Table 2: Sample Size

\begin{tabular}{|l|l|l|l|l|l|l|}
\hline Category of School & $\begin{array}{l}\text { Clas } \\
\text { s }\end{array}$ & $\begin{array}{l}\text { No in } \\
\text { Class }\end{array}$ & $\begin{array}{l}\text { Number } \begin{array}{l}\text { Number sampled } \\
\text { struggling } \\
\text { readers }\end{array} \\
\text { Control }\end{array}$ & $\begin{array}{l}\text { Experiment } \\
\text { al }\end{array}$ & Total \\
\hline Government G.S. Bonduma 1 & 5 & 26 & $16(61.5 \%)$ & 4 & 4 & 8 \\
\hline Mission C.B.C. mile 16 & 5 & 18 ev & $14(77.8 \%)$ & 4 & 4 & 8 \\
\hline $\begin{array}{l}\text { Lay private Bonandive } \\
\text { Academic Centre }\end{array}$ & 5 & 17 & $10(58.8 \%)$ & 4 & 4 & 8 \\
\hline Total & & 61 & 40 & 120 & 12 & 24 \\
\hline
\end{tabular}

The sample size for this study was 24 participants (18 boys and 6 girls) drawn from three primary schools (government, mission, and private) within Buea municipality. Eight pupils participated from each school. The criterion for participation was that the pupils from each school must be in class five, must be aged between 9- 11 years, must be a struggling reader and could be male or female. Out of the 61 struggling readers in the three schools, 24 of them were sampled. Class 5 was chosen because it is the last but one class in the primary school where pupils are expected to have acquired visual discrimination skills to enable them read age appropriate literature before graduation.

According to Picciano (1996), a sample size can be determined by using sampling theories or determined by the nature of the research. Also he stresses that experimental studies could tolerate a minimal samples sizes for statistical significance to be valued and that even a school could be chosen for such studies. To buttress this point Gall and Borg (2015) states that causal comparative and experimental research methodology can tolerate a sample size of fewer than 15 participants in each group because it is out to establish the relationship that exist between the variables.

\section{SAMPLING TECHNIQUES \\ Selection of schools}

The selection of schools was done considering the nature of the study which sought to establish the relationship between variable and also following the stratified simple random sampling method. According to McMillan(1996) and Cohen, Monion and Morrison (2007) there is no precise way of generalising judgmental or convenient sample of the population considering that such studies sought to establish the 
relationship that exist between variable They stress that such studies could be carried out even in a single school and the results indicate the relationship. They argue that once the relation has been determined spending longer periods in the field will be a waste of time. They recommend that if there is need for generalisation same study could be carried out in different geographical areas. Three schools were selected through stratified simple random sampling whereby within each category of school was represented.

\section{Selection of participants}

Participants were selected purposively through a multi-stage screening. The first stage consisted of teacher nomination, the second stage the examination of their class records and the third stage through a standard test. During this phase, all the nominee were subjected to an oral reading test to ascertain that they were struggling readers using Gray's Oral Reading Test (GORT-5) (Patino; 2014). This test was out to measure reading fluency and comprehension. Participants weregiven a short passage to read to and answer questions from the passage. The researcher to suit the level of the learners constructed the short passage. She adopted the scoring scale from Gray's oral reading test(GORT-5 (Patinon2014).The researcher observed and followed along as each participant read. She took note on the errors, fluency, and comprehension of the passage. For each correct word the child, scored (.5) mark while comprehension was scored (2 marks).The grading wasdone on a scale of 20.Then; the last eight participants with the least score in each school were taken for the study.

"Dig a hole and feed the pig. He left for school and did not get to the pig. His father saw him and was happy. But did not know that he left the pig without food".

\section{Question}

What is the passage about?

Table 3: Score sheet for oral reading Test (GORT-5)

\begin{tabular}{|c|c|c|c|}
\hline SN & $\begin{array}{c}\text { G.P.S.Bon } \\
\text { dumaGrou } \\
\text { p 1-16 }\end{array}$ & $\begin{array}{c}\text { C.B.C.Bolif } \\
\text { ambalile } \\
16-14\end{array}$ & $\begin{array}{c}\text { Bonandive } \\
\text { Academic } \\
\text { Centre- } \mathbf{1 0}\end{array}$ \\
\hline 1 & 14.5 & 13.5 & 13.5 \\
\hline 2 & 14 & 12.5 & 13 \\
\hline 3 & 14 & 12.5 & 13 \\
\hline & 13.5 & 12 & 12.5 \\
\hline & 13.5 & 12 & 12.5 \\
\hline 4 & 13 & 12 & 12.5 \\
\hline 5 & 13 & 11.5 & 12 \\
\hline 6 & 12.5 & 11 & 11.5 \\
\hline 7 & 12 & 11 & 11 \\
\hline 8 & 11 & 11 & 10 \\
\hline 9 & 10 & 10 & 19 \\
\hline 10 & 10 & 9 & 8 \\
\hline 11 & 9 & 8 & \\
\hline 12 & 8 & 8 & \\
\hline 13 & 7 & 7 & \\
\hline 14 & 6 & 6 & \\
\hline 15 & 6 & & \\
\hline 16 & 5 & & \\
\hline
\end{tabular}

The Participant were later divided into the controlled and experimental group at random. This process is diagrammatically represented on the sample flow chart below as in Nana (2015).

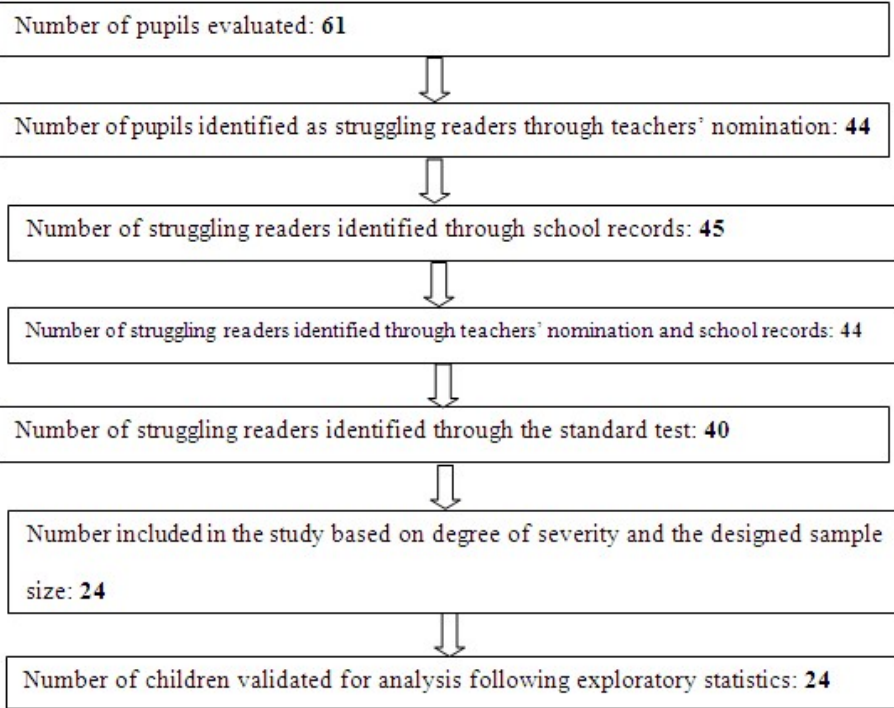

Figure 3: Summary of the Identification Process

\section{Instrument for Data Collection}

Data triangulation was employed in the study. This involved collecting data qualitatively through interviews, and quantitatively through test scores. The following instruments were used: 
$>$ A master sheet for reading assessment for pre-test, post-test.

$>$ Test score sheets from researcher-made test that enabled the researcher to monitor the progress made by the participant in the experimental group.

$>$ Interview guide for pupils also enabled the researcher to collect more information from the participants on the difficulties that struggling readers' experiences with reading and how they affects their personality development.

$>$ Interview guide for teachers enabled the researcher to collect information from the class teacher as to whether they are able to recognize struggling readers in their classroom and how they meet their needs.

\section{DESCRIPTION OF INSTRUMENTS}

\section{The master plan activity sheet}

The master plan activity sheet was structured into two phases. Section A: was focused on demographic data to enable the researcher collect some personal information about the individual pupil, while section $\mathrm{B}$ : focused on instruction and section $\mathrm{C}$ : focused on knowledge items. It contained 20 items directed towards testing the pupils' visual discrimination skills on letters, words, numbers, geometric shapes and picture images. Items 1-4 focused on testing the participants' visual discrimination skills with respect to recognition of capital letters, small letters, easily confusing letters and their similarities and differences. Items 5-9 focused on testing the pupils' visual discrimination skills of words, spelt with same letters at different positions, identification of specified words with similar endings, and the similarities and differences of specified words. Items 9-12 focused on testing the participants' visual discrimination skills for numbers. Pupils were tested on identifying single digit numbers, double digit numbers, place value of specified numbers and similarities and differences of specified numbers. Items 13-16 was focused on testing pupils' visual discrimination skills for geometric shapes. Pupils were tested on their ability to identify specified shapes, their similarities and differences, number of sides, and shapes within a specified shape. For items, 17-20 the focus was on testing participants' ability to visually discriminate among pictures provided. Pupils were tested on their ability to identify similar pictures, their similarities and differences, and also to identify the missing features in the pictures.
All the items were evaluated on a frequency count from 1-4 on a duration of 60 seconds. Each pupil was given up to 60 seconds (1minute) to respond to the item presented. If the child provided the right response within the period of one minute, he or she was graded as follows. Less than $25 \mathrm{sec}=1$ (very mild), less than $35 \mathrm{sec}=2$ (mild), less than $45 \mathrm{sec}=3$ (severe) less than $60 \mathrm{sec}=4$ (very severe). Items for which the wrong response was given or not given at all were scored 4. This implies that the earlier the response given the higher the Childs' visual discrimination skills and the later the response provided the lesser the child visual discrimination skills. This was intended to help the researcher to observe if the pupils were having visual discrimination difficulties with letters, words, numbers, shapes and picture images before applying the treatment exercise. This guided the researcher to prepare an appropriate treatment exercise to improve the visual discrimination skills for struggling readers in primary five.

This instrument was adapted from the master sheet of reading assessment for primary schools in Nigeria, constructed by professor Ihenacho for the University of Jos Nigeria (1986). This was because it gives a general view on certain issues related to reading difficulties and ensured that the particular requirements for visual discrimination training on the recognition of items was fulfilled. The technique of frequency count was adopted while the other items were modified to suit the study, which was focused on visual discrimination training.

\section{Test score sheet}

The test score sheet for assessing the struggling readers during the treatment exercise was designed by the researcher. They were meant to assess if the treatment was achieving its objectives. The scores sheets was structured into two sections. Section A: contained demographic data, while section B: contained knowledge items. The scores for each item were indicated against the items throughout the evaluation for each school. Test 1 had 8 items and was focused on testing pupils' ability to recognise similarities and differences in letters and words while test 2; had 12 items which dwelled on pupils' ability to recognise similarities and differences in numbers, geometric shapes and pictures. Pupils in each school were tested on the same instructions. 


\section{Interview Guide for Pupils}

The interview guide for teachers was also structured into 3 sections as follows; Section A demographic data, section B psychological data, Section C: knowledge items. The psychological items were 9 and they focused on finding out if pupils would like to learn how to read and how they felt when they were ridiculed because they could not read. They were also interviewed on the difficulties they faced with reading and who they expected to help them read. The assistance they needed from their parents, teachers and the school was also sought. Besides, they were interviewed on what the school could do to help struggling reads to be able to read and if they think their inability to read they affected their academic performance. More so, the researcher wanted to know if they were happy with the massive promotion that is practiced in school and why. While section $\mathrm{C}$ was focused on testing them orally if they could recognise the similarities and differences in letters, words, numbers, geometric shapes and pictures. (See appendix E). The purpose of this instrument was to get more information about the difficulties that some struggling readers face with reading and their feeling about their performance.

\section{Interview guide for teachers}

The interview guide for teachers was structured in 2 sections. Section A was focussed on demographic data while section $\mathrm{B}$ was focused on pedagogic knowledge. The pedagogic section had 10 items, which focused on investigating whether the teachers could identify struggling readers in their classrooms and their opinion why some children struggle with reading. Their views were also sought on what the children can do to be able to read, what parents could do to help their children read and what the teachers could also do to help the struggling readers in their classrooms and schools to read. Besides, they were interviewed on what the school could do to enable struggling readers read, what strategies could be used to help struggling readers recognize letters, words, numbers, geometric shapes and pictures. Further more teachers were asked of the strategies that could be used to help children read and to nurture in them the reading culture. The interview guide for teachers constructed by the researcher was aimed at getting more information from the teacher about the struggling readers and their perception about their struggling condition in reading.

\section{Validity and Reliability of Instrument}

Validation of research instrument is very important to ensure that the instruments measure what they intended to measure. This was done in two phases.

\section{Content Validity}

To ensure the content validity, the research instruments were constructed and presented to a specialist in learning disabilities to ascertain whether the instruments suit the characteristics of the learners or not. Thereafter, the same instruments were presented to the supervisor for scrutiny. This led to some modification $\mathrm{n}$ and adjustment of some items to ensure that the objectives of the study are attained.

\section{FACE VALIDITY}

\section{Pilot Test}

The researcher carried out a pilot test with four struggling readers in G.P.S Bonadikombo mile 4 Limbe that had the same characteristics with the participants and was not part of the sample population to check for any ambiguity in content. They were nominated by the class teacher and subjected to an oral reading test by the researcher. The purpose was to ascertain their status as struggling readers. They were later assign to the experimental and control group through simple random sampling. The researcher administered the test to the four participants. The class teacher taught those in the experimental group for two weeks using the scheme produced by the researcher for this study while those in the control group received no such treatment. After two weeks, the four participants were subjected to a second test. They were further exposed to a semi-structured interview to get more information about the difficulties they face with reading. No major discrepancy was observed and the teacher concluded that the test items were well understandable and within the level of the pupils.

\section{Reliability of the Instruments}

The test-retest reliability test was used in the study. The same test was administered (as pre-test and posttest) to the same set of respondents after intervention with the experimental group by the class teacher. Then, the results of the two tests were compared and analysed using Cronbach's alpha with the formula:

$: a=\frac{N \cdot \bar{C}}{\bar{V}+(N-1) \cdot \bar{C}}$ Where $\mathrm{N}=$ No. of items, $\bar{C}=$ Average inter item covariance

$\bar{V}=$ Average Variance, $\mathrm{a}=$ Cronbach alpha reliability 
Note: the higher the item, the higher the alpha and the lower the item the lower the alpha

The progression was computed based on the differences in scores between the two tests. The evaluation was based on frequency count as follows: very mild-4; mild-3; servere-2; very servere-1; the four grading were later collapsed to two grading (mild and severe) to enable the researcher draw inferences as to whether the progression was positive or negative. That is, a participant with mild status at pretest and very mild at post-test for instance will be considered as having progressed just like one with very severe at post-test will be considered that he or she has not progressed. Meaning that the disability has not improved,

Cronbach Alpha reliability coefficient was big enough $($ Alpha $=0.733)$ implying that responses were consistent in their trend. The internal consistency assumption therefore is not violated.

\section{Experimental Procedure}

After the selection of the schools, the researcher began with the experiment. She constructed a timetable to guide her schedules to the selected schools. When she got to each schools, she went straight to the head teachers office to obtain permission and to explain the purpose of her visit. She was later led to the classrooms were she informed the pupils and their teachers of the purpose of her visit. Then, the class teachers nominated the struggling readers in their respective classroom. All the nominee were subjected to multiple sampling (teacher nomination, observation of the progress record chart and Gray's oral reading test) those with the eight worst marks were chosen for the study while the rest were sent back to their classroom. All the eight participants were tested on the same day using the same instrument and scoring scale. This was to ensure that there was no sampling bias.

On such a situation, the researcher's time table was not strictly followed. She got to the school by 7:30 am and worked with individual pupil. Testing for each individual lasted for 20 minutes until all the eight participant in the school were tested. Teaching commenced with the next visit to the school following the researcher's time table. Only those in the experimental group received the intervention while those in the control group when back to class to continue with their normal classes. These interventions were guided by the scheme of work produced by the researcher. Teaching continued throughout the weeks for four weeks in all the school. After four weeks of teaching the first evaluation was given to check if the treatment exercise was having any positive effect on the development of visual discrimination skills for the participants. Individual scores were recorded while teaching continued. Four weeks later the second evaluation test was given and the scores recorded and compared with the previous individual scores to check for improvement. This was followed by revision and the administering of the post-test to the 24 participant following the principles observed during the pre-test. During the last week when the participants were already relaxed with the researcher, interviews were conducted to get more information on the difficulties that struggling readers face with reading and their feeling about their status as struggling readers. The interview in each school lasted for $1 \mathrm{hr} 20$ minutes considering that each participant had about 10 minutes. The class teachers were also interviewed on their perception about struggling readers and their pedagogic knowledge in handling them. This lasted for about 15 minutes with each teacher having 5 minutes.

In all, the researcher spent 10 weeks in the field visiting each school thrice a week to collect the data. A total of 25 hours 45 minutes were spent in the field as follows; Pre-test:2hours 40 minutes (20minutes each), post-test:2hours 40 minutes (20 minutes each), interview for pupils: $1 \mathrm{hr}$ hours (7miniutes each) interviews for teachers 15 minutes (5minutes each) and 17 hours 30 minutes for interaction and teaching with the experimental group. The mean scores of the two groups (experimental and control) were compared and inferences drawn, interpretation and discussion made based on the findings

\section{Method of Data Collection}

Data was collected qualitatively and quantitatively to minimise bias. After the identification of the participants, the 24 participants were subjected to a pre-test. This was followed by the administration of the treatment exercise only to the experimental group. During this period, those in the experimental group were tested twice to check if the treatment exercise was achieving its objectives. Thereafter, a post-test was administered to the 24 participants to find out if there was any improvement with the experimental group that received the treatment exercise. Later the participants and their teachers were subjected to 
interviews to get more information about their difficulties with reading and how the teachers handle this situation in school. A total of 25 hours 45 minutes were spent in the field Data was transcribed descriptively, inferentially and into themes to ease analysis and the drawing of inferences.

The organization of study indicators that led to the various variables under their respective hypothesis is summarized in the table on the operationalization of variables below.

\section{Data Processing and Analysis}

Data were entered using Epi Info 6.04d (CDC, 2001), after template was tested by statistician and candidate. Data were then exported to SPSS version 21.0 (IBM Inc., 2012). Descriptive analysis employed frequency, proportion and Multiple-Responses Analysis (MRA) as the variables were categorical.

Progression was computed based on the difference in score between two tests. The various levels of performance were given scores as follow: very mild $=4$; mild $=3$; severe $=2$; very severe $=1$. A participant with mild status at pre-test and very mild at post test for instance, was considered as having progressed, this was same with a participant with very severe at pre-test and severe at post-test. The differences between the experimental and control groups were carried out using Chi Square Test of Equality of Proportions.
Interviews were analysed using the process of thematic analysis whereby concepts or ideas were grouped under umbrella terms or key words.

Results were summarized in tables, charts, conceptual diagrams and code-grounding-quotation tables. Statistics were discussed at the $95 \%$ CL (Alpha=0.05).

\section{Ethical Consideration}

The participants were informed about the study and asked to volunteer through nomination. They were assured that any information provided for this study will be confidential and will serve just the purpose for which it is intended. Permission was sought from their parents and the school administration to get their consent. To ensure their protection, their names were concealed and the pupils given numbers to ease accountability. Only those that were willing took part in the study.

\section{FINDINGS}

Four items were tested. They sought to investigate if struggling readers trained to recognise specified pictures, recognising similarities in pictures, recognising missing features in similar looking pictures and recognising differences in pictures can read better than their peers who received no such training as it is shown below in all scales.

\section{PRE-TEST}

Table 32:Ability to Work with Picture Images at Pre-test: Experimental Group

\begin{tabular}{|c|c|c|c|c|c|c|c|}
\hline Ability to Work with Picture & \multirow{2}{*}{$\begin{array}{l}\text { Very } \\
\text { Mild }\end{array}$} & \multirow[t]{2}{*}{ Mild } & \multirow[t]{2}{*}{ Severe } & \multirow{2}{*}{$\begin{array}{l}\text { Very } \\
\text { Severe }\end{array}$} & \multicolumn{2}{|l|}{ Collapse } & \multirow[t]{2}{*}{$\mathbf{N}$} \\
\hline Experimental Group & & & & & Mild & Severe & \\
\hline Sort out picture that look the same? & $4(33.3 \%)$ & $1(8.3 \%$ & $\begin{array}{l}1(8.3 \\
\%)\end{array}$ & $\begin{array}{l}6(50.0 \\
\%)\end{array}$ & $5(41.7 \%)$ & $7(58.3 \%)$ & 12 \\
\hline What makes them look the same? & $0(0.0 \%)$ & $\begin{array}{l}3(25.0 \\
\%)\end{array}$ & $\begin{array}{l}0(0.0 \\
\%)\end{array}$ & $\begin{array}{l}9(75.0 \\
\%)\end{array}$ & $3(25.0 \%)$ & $9(75.0 \%)$ & 12 \\
\hline What makes them look different? & $0(0.0 \%)$ & $\begin{array}{l}0(0.0 \% \\
)\end{array}$ & $\begin{array}{l}0(0.0 \\
\%)\end{array}$ & $\begin{array}{l}12(100 \\
\%)\end{array}$ & $0(0.0 \%)$ & $12(100.0 \%$ & 12 \\
\hline Identify the missing features? & $0(0.0 \%)$ & $\begin{array}{l}0(0.0 \% \\
)\end{array}$ & $\begin{array}{l}0(0.0 \\
\%)\end{array}$ & $\begin{array}{l}12(100 . \\
0 \%)\end{array}$ & $0(0.0 \%)$ & $12(100.0 \%$ & 12 \\
\hline Multiple Response Set (MRS) & $4(8.3 \%)$ & $\begin{array}{l}4(8.3 \% \\
)\end{array}$ & $\begin{array}{l}1(2.1 \\
\%)\end{array}$ & $\begin{array}{l}39(81.3 \\
\%)\end{array}$ & $8(16.7 \%)$ & $40(83.3 \%)$ & 48 \\
\hline
\end{tabular}

The above table reveals that out of the 12 participants in the experimental group $4(41 \%)$ had mild difficulties in sorting similar pictures while $7(58.3 \%)$ had severe difficulties in sorting similar pictures). 
Also, $3(25 \%)$ of the struggling readers had mild difficulties in identifying similarities in the pictures while $9(75 \%)$ of them had severe difficulties identifying such similarities.

More so, all the 12(100\%) participants had severe difficulties identifying what makes the pictures different Also, For identifying the missing feature in the picture all the 12 participant had severe difficulties with the identification of shapes within the shape.

Table 33:Ability to work with picture images at pre-test: Control group

\begin{tabular}{|c|c|c|c|c|c|c|c|}
\hline Ability to work with picture & \multirow[t]{2}{*}{ Very mild } & \multirow[t]{2}{*}{ Mild } & \multirow[t]{2}{*}{ Severe } & \multirow{2}{*}{$\begin{array}{l}\text { Very } \\
\text { severe }\end{array}$} & \multicolumn{2}{|c|}{ Collapse } & \multirow[t]{2}{*}{$\mathbf{N}$} \\
\hline Control group & & & & & Mild & Severe & \\
\hline $\begin{array}{l}\text { Sort out pictures that look the } \\
\text { same? }\end{array}$ & $5(41.7 \%)$ & $1(8.3 \%)$ & $\begin{array}{l}2(16.7 \\
\%)\end{array}$ & $\begin{array}{l}4(33.3 \% \\
)\end{array}$ & $\begin{array}{l}6(50.0 \\
\%)\end{array}$ & $\begin{array}{l}6(50.0 \\
\%)\end{array}$ & 12 \\
\hline What makes them look the same? & $1(8.3 \%)$ & $2(16.7 \%$ & $\begin{array}{l}1(8.3 \% \\
)\end{array}$ & $\begin{array}{l}8(66.7 \% \\
)\end{array}$ & $\begin{array}{l}3(25.0 \\
\%)\end{array}$ & $\begin{array}{l}9(75.0 \\
\%)\end{array}$ & 12 \\
\hline What makes them look differe & $1(8.3 \%)$ & $0(0.0 \%)$ & $\begin{array}{l}3(25.0 \\
\%)\end{array}$ & $\begin{array}{l}8(66.7 \% \\
)\end{array}$ & $\begin{array}{l}1(8.3 \% \\
)^{1}\end{array}$ & $\begin{array}{l}11(91.7 \\
\%)\end{array}$ & 12 \\
\hline Identify the missing features & $1(8.3 \%)$ & $0(0.0 \%)$ & $\begin{array}{l}2(16.7 \\
\%)\end{array}$ & $\begin{array}{l}975.0(\% \\
)\end{array}$ & $\begin{array}{l}1(8.3 \% \\
)^{2}\end{array}$ & $\begin{array}{l}11(91.7 \\
\%)\end{array}$ & 12 \\
\hline Multiple Responds Set (MRS) & $8(16.7 \%)$ & $3(6.3 \%)$ & $\begin{array}{l}8(16.7 \\
\%)\end{array}$ & $\begin{array}{l}29(60.4 \\
\%)\end{array}$ & $\begin{array}{l}11(22.9 \\
\%)\end{array}$ & $\begin{array}{l}37(77.1 \\
\%)\end{array}$ & 48 \\
\hline
\end{tabular}

The table above shows that out of the 12 participants in the control group $6(50 \%)$ of them had mild difficulties sorting pictures specified. while $6(50 \%)$ also had severe difficulties. Also, for the identification of what make them similar 3(25.0\%)had mild difficulties while $9(75 \%)$ of them had severe difficulties. For the identification of what makes them different $1(8.3 \%)$ had mild difficulties identifying what makes the pictures different. While $11(91 \%)$ of them had severe difficulties. More so for identifying the missing features in the pictures $1(8.3 \%)$ had mild difficulties while $11(91.7 \%)$ had severe difficulties. The multiple response set revealed that 11 $(22.9 \%)$ had mild difficulties while $37(77.1 \%)$ had severe difficulties working with pictures.

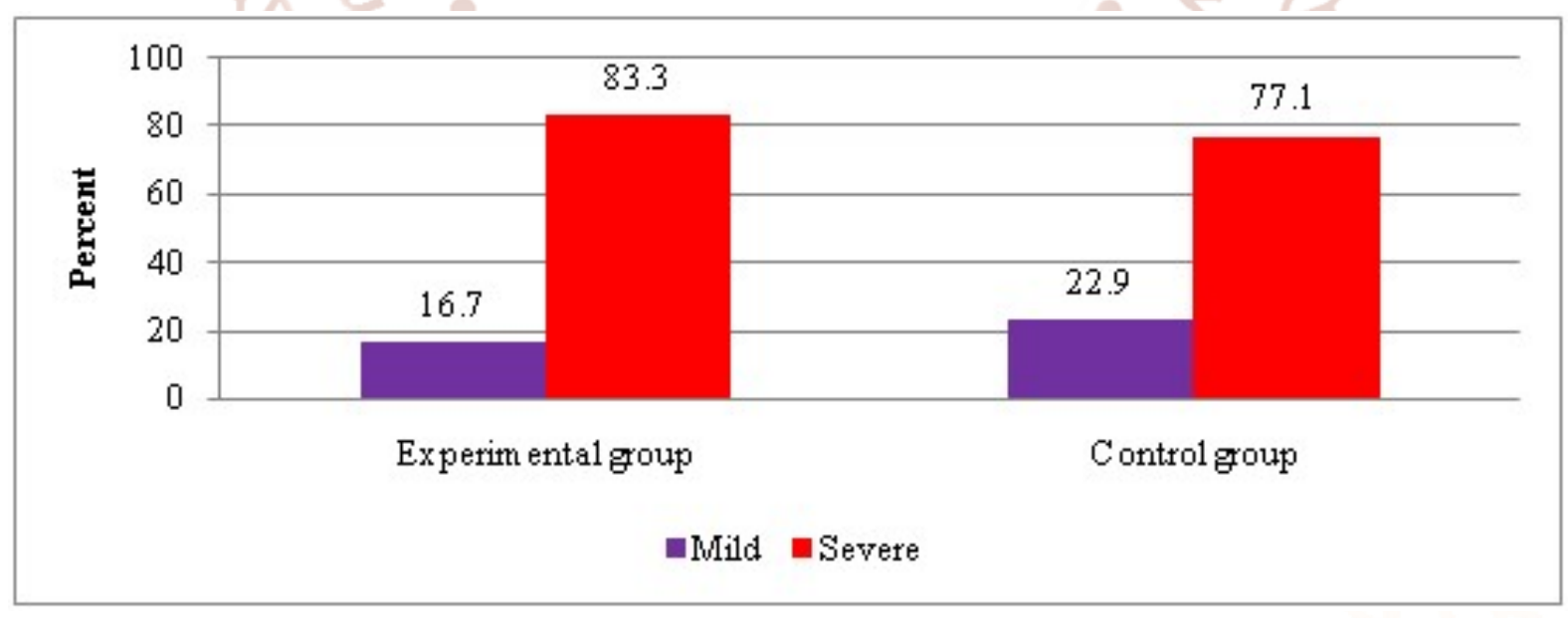

$\chi 2$-test: $\chi 2=0.00 ; \mathrm{df}=1 ; \mathrm{P}=1.00$

Figure 24: Comparing Children Status at Pre-test between Control and Experimental Group for Ability to Work with Picture Images

The initial status of the children indicates that in both the experimental and the control group, the majority had severe disabilities with proportion of $83.3 \%$ (MRS: nresponses $=40)$ and $77.1 \%$ (MRS: nresponses $=37$ ) for the experimental and control group respectively and the difference here was not significant ( $\chi 2$-test: $\mathrm{P}>0.05)$, which is good for the validity of the data. 
International Journal of Trend in Scientific Research and Development (IJTSRD) ISSN: 2456-6470

FORMATIVE

Table34: Ability to Work with Picture Images at Formative Evaluation: Experimental Group

\begin{tabular}{|c|c|c|c|c|c|c|c|}
\hline Ability to Work with Picture & \multirow{2}{*}{$\begin{array}{l}\text { Very } \\
\text { Mild }\end{array}$} & \multirow[t]{2}{*}{ Mild } & \multirow[t]{2}{*}{ Severe } & \multirow{2}{*}{$\begin{array}{l}\text { Very } \\
\text { Severe }\end{array}$} & \multicolumn{2}{|c|}{ Collapse } & \multirow[t]{2}{*}{$\mathbf{N}$} \\
\hline Experimental Group & & & & & Mild & Severe & \\
\hline Sort out picture that look the same? & $\begin{array}{l}2 \\
(16.7 \%)\end{array}$ & $\begin{array}{l}3 \\
(25.0 \%) \\
\end{array}$ & $\begin{array}{l}7 \\
(58.3 \%) \\
\end{array}$ & $\begin{array}{l}0 \\
(0.0 \%)\end{array}$ & $\begin{array}{l}5 \\
(41.7 \%) \\
\end{array}$ & $\begin{array}{l}7 \\
(58.3 \%) \\
\end{array}$ & 12 \\
\hline What makes them look the same? & $\begin{array}{l}1 \\
(8.3 \%)\end{array}$ & $\begin{array}{l}8 \\
(66.7 \%)\end{array}$ & $\begin{array}{l}2 \\
(16.7 \%)\end{array}$ & $\begin{array}{l}1 \\
(8.3 \%)\end{array}$ & $\begin{array}{l}9 \\
(75.0 \%)\end{array}$ & $\begin{array}{l}3 \\
(25.0 \%)\end{array}$ & 12 \\
\hline What makes them look different? & $\begin{array}{l}1 \\
(8.3 \%)\end{array}$ & $\begin{array}{l}6 \\
(50.0 \%)\end{array}$ & $\begin{array}{l}4 \\
(33.3 \%)\end{array}$ & $\begin{array}{l}1 \\
(8.3 \%)\end{array}$ & $\begin{array}{l}7 \\
(58.3 \%)\end{array}$ & $\begin{array}{l}5 \\
(41.7 \%)\end{array}$ & 12 \\
\hline Identify the missing features? & $\begin{array}{l}1 \\
(8.3 \%)\end{array}$ & $\begin{array}{l}5 \\
(41.7 \%)\end{array}$ & $\begin{array}{l}4 \\
(33.3 \%)\end{array}$ & $\begin{array}{l}2 \\
(16.7 \%\end{array}$ & $\begin{array}{l}6 \\
(50.0 \%)\end{array}$ & $\begin{array}{l}6 \\
(50.0 \%)\end{array}$ & 12 \\
\hline Multiple Response Set (MRS) & $\begin{array}{l}5 \\
(10.4 \%)\end{array}$ & $\begin{array}{l}22 \\
(45.8 \%)\end{array}$ & $\begin{array}{l}17 \\
(35.4 \%)\end{array}$ & $\begin{array}{l}4 \\
(8.3 \%)\end{array}$ & $\begin{array}{l}27 \\
(56.3 \%)\end{array}$ & $\begin{array}{l}21 \\
(43.8 \%)\end{array}$ & 48 \\
\hline
\end{tabular}

The table above reveals that at the level of formative test out of the 12 participants $5(41.7 \%)$ had mild difficulties with sorting of specified pictures while $7(58 \%)$ had severe difficulties. Also for the ability to sort pictures that look the same $9(75 \%)$ of the had mild difficulties while $3(25 \%)$ of them had severe difficulties with this item. For the pictures that look different,7(58.3\%)had mild difficulties while 5(41.7\%) had severer difficulties. Regarding the ability to identify the missing features in the pictures $6(50.0 \%)$ had mild difficulties while $6(50 \%$ of them also had severe difficulties identifying missing features in the displayed pictures. Them, the multiple response set shows that $27(56.3 \%)$ had mild difficulties while $21(43.8 \%)$ had severe disabilities with pictures.

\section{Post-test}

Table 35:Ability to Work with Picture Images at Post-Test: Experimental Group

\begin{tabular}{|c|c|c|c|c|c|c|c|}
\hline Ability to Work with Picture & \multirow{2}{*}{$\begin{array}{l}\text { Very } \\
\text { mild }\end{array}$} & \multirow[t]{2}{*}{ Mild } & \multirow[t]{2}{*}{ Severe } & \multirow{2}{*}{$\begin{array}{l}\text { Very } \\
\text { Severe }\end{array}$} & \multicolumn{2}{|c|}{ Collapse } & \multirow[t]{2}{*}{$\mathbf{N}$} \\
\hline Experimental Group & & & & & Mild & Severe & \\
\hline Sort out pictures that look the sam & $\begin{array}{l}4 \\
(33.3 \%)\end{array}$ & $\begin{array}{l}7 \\
(58.3 \%)\end{array}$ & $\begin{array}{l}1 \\
(8.3 \%)\end{array}$ & $\begin{array}{l}0 \\
(0.0 \%)\end{array}$ & $\begin{array}{l}11 \\
(91.7 \%)\end{array}$ & $\begin{array}{l}1 \\
(8.3 \%)\end{array}$ & 12 \\
\hline What makes them look the same? & $\begin{array}{l}3 \\
(25.0 \%)\end{array}$ & 6 & $\begin{array}{l}2 \\
(16.7 \%)\end{array}$ & 1 & 9 & $\begin{array}{l}3 \\
(25.0 \%)\end{array}$ & 12 \\
\hline What makes them look different? & $\begin{array}{l}2 \\
(16.7 \%)\end{array}$ & $\begin{array}{l}6 \\
(50.0 \%)\end{array}$ & $\begin{array}{l}4 \\
(33.3 \%)\end{array}$ & $\begin{array}{l}0 \\
(0.0 \%)\end{array}$ & $\begin{array}{l}8 \\
(66.7 \%)\end{array}$ & $\begin{array}{l}4 \\
(33.3 \%)\end{array}$ & 12 \\
\hline Identify the missing features? & $\begin{array}{l}2 \\
(16.7 \%)\end{array}$ & $\begin{array}{l}5 \\
(41.7 \%)\end{array}$ & $\begin{array}{l}4 \\
(33.3 \%)\end{array}$ & $\begin{array}{l}1 \\
(8.3 \%)\end{array}$ & $\begin{array}{l}7 \\
(58.3 \%)\end{array}$ & $\begin{array}{l}5 \\
(41.7 \%)\end{array}$ & 12 \\
\hline Multiple Response Set (MRS) & $\begin{array}{l}11 \\
(22.9 \%)\end{array}$ & $\begin{array}{l}24 \\
(50.0 \%)\end{array}$ & $\begin{array}{l}11 \\
(22.9 \%)\end{array}$ & $\begin{array}{l}2 \\
(4.2 \%)\end{array}$ & $\begin{array}{l}35 \\
(72.9 \%)\end{array}$ & $\begin{array}{l}13 \\
(27.1 \%)\end{array}$ & 48 \\
\hline
\end{tabular}

From the table above it revealed that out of the 12 pupils in the experimental group at post-test $11(91.7 \%)$ of them have mild difficulties with sorting of pictures that look the same while only $1(8.3 \%)$ still had severe difficulties. While for the ability to identify what makes them look the same $9(75.0 \%)$ had mild difficulties while $3(25.0 \%)$ still had severe difficulties. As for the ability to identify what makes them different $8(66.7 \%)$ had mild difficulties while $4(33.3 \%)$ still had severe difficulties. Then, for the ability to identify the missing features, $7(58.3 \%)$ had mild difficulties while $5(41.7 \%)$ still had severe difficulties. 
The response set reveals that 35(72.9\%) had mid difficulties while 13(27.1\%)still had severe difficulties.

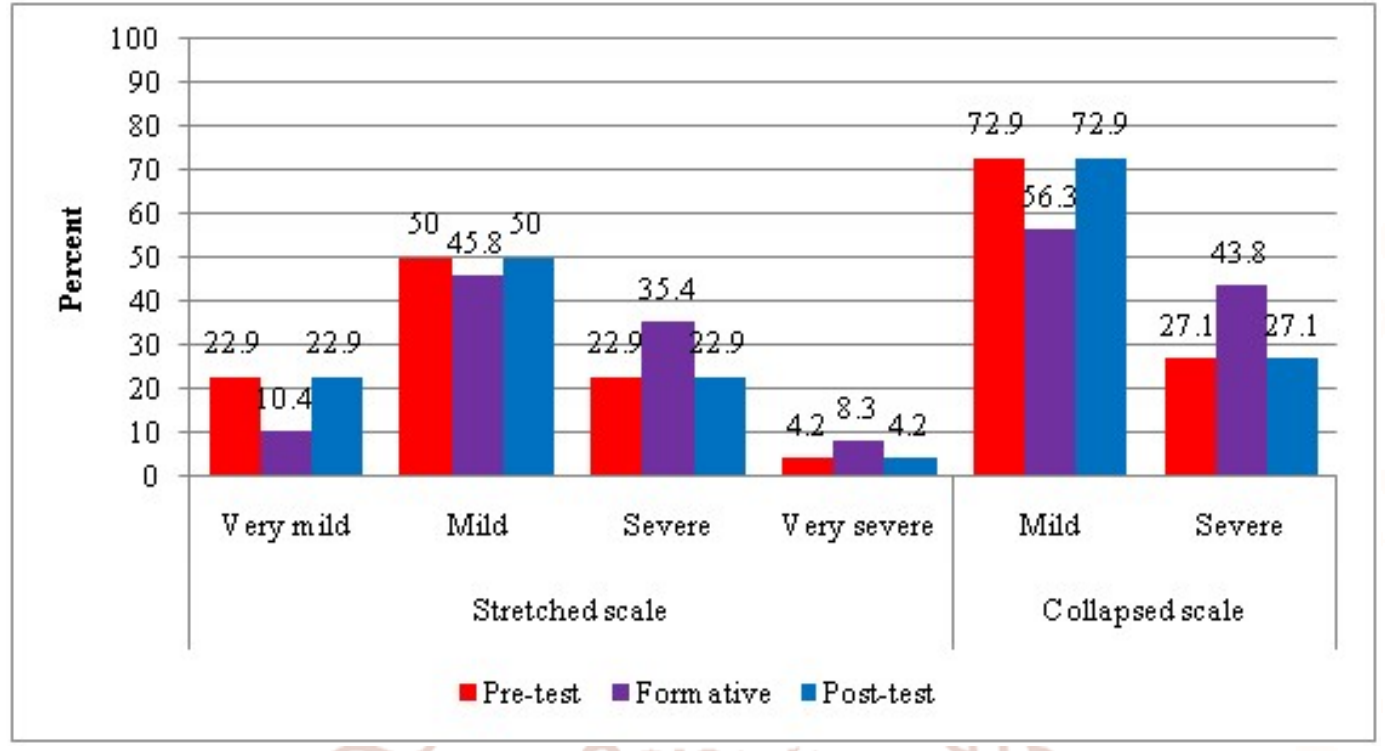

$\chi 2$-test: $\chi 2=1.05 ; \mathrm{df}=2 ; \mathrm{P}=0.592$.

Figure 25: Change in Disability Status in the Experimental Group for Ability to Work with Picture Images

There was no obvious improvement in the condition of the children in the experimental group. The proportion of children with severe visual discrimination disability instead increased from $27.1 \%$ at pre-test to $43.8 \%$ at the formative evaluation before dropping to $27.1 \%$ at post-test and this change was significant $(\chi 2$-test: $\mathrm{P}=0.592)$.

Table 36: Ability to Work with Picture Images at Post-Test: Control Group

\begin{tabular}{|c|c|c|c|c|c|c|c|}
\hline Ability to Work with Picture & \multirow{2}{*}{$\begin{array}{l}\text { Very } \\
\text { Mild }\end{array}$} & \multirow[t]{2}{*}{ Mild } & \multirow[t]{2}{*}{ Severe } & \multirow{2}{*}{$\begin{array}{l}\text { Very } \\
\text { Severe }\end{array}$} & \multicolumn{2}{|l|}{ Collapse } & \multirow[t]{2}{*}{$\mathbf{N}$} \\
\hline Control Group & & & & & Mild & $\overline{\mathrm{Sev}}$ & \\
\hline $\begin{array}{l}\text { Sort out picture that look the } \\
\text { same? }\end{array}$ & $\begin{array}{l}3 \\
(25.0 \%)\end{array}$ & $\begin{array}{l}4 \\
(33.3 \%) \\
\end{array}$ & 2 & $\begin{array}{l}3 \\
(25.0 \%)\end{array}$ & $\begin{array}{l}7 \\
(58.3 \%)\end{array}$ & $\begin{array}{l}5 \\
(41.7 \%) \\
\end{array}$ & 12 \\
\hline $\begin{array}{l}\text { What makes them look the } \\
\text { same? }\end{array}$ & $\begin{array}{l}1 \\
(8.3 \%) \\
\end{array}$ & $\begin{array}{l}1 \\
(8.3 \%)\end{array}$ & 1 & $\begin{array}{l}9 \\
(75.0 \%)\end{array}$ & $\begin{array}{l}2 \\
(16.7 \%)\end{array}$ & $\begin{array}{l}10 \\
(83.3 \%)\end{array}$ & 12 \\
\hline $\begin{array}{l}\text { What makes them look } \\
\text { different? }\end{array}$ & $\begin{array}{l}0 \\
(0.0 \%)\end{array}$ & $\begin{array}{l}2 \\
(16.7 \%)\end{array}$ & $\begin{array}{l}0 \\
(0.0 \%) \\
\end{array}$ & $\begin{array}{l}10 \\
(83.3 \%)\end{array}$ & $\begin{array}{l}2 \\
(16.7 \%)\end{array}$ & $\begin{array}{l}10 \\
(83.3 \%)\end{array}$ & 12 \\
\hline Identify the missing features? & $\begin{array}{l}0 \\
(0.0 \%)\end{array}$ & $\begin{array}{l}2 \\
(16.7 \%)\end{array}$ & $\begin{array}{l}0 \\
(0.0 \%)\end{array}$ & $\begin{array}{l}10 \\
(83.3 \%)\end{array}$ & $\begin{array}{l}2 \\
(16.7 \%)\end{array}$ & $\begin{array}{l}10 \\
(83.3 \%)\end{array}$ & 12 \\
\hline Multiple Responds Set (MRS) & $\begin{array}{l}4 \\
(8.3 \%)\end{array}$ & $\begin{array}{l}9 \\
(18.8 \%)\end{array}$ & $\begin{array}{l}3 \\
(6.3 \%)\end{array}$ & $\begin{array}{l}32 \\
(66.7 \%)\end{array}$ & $\begin{array}{l}13 \\
(27.1 \%)\end{array}$ & $\begin{array}{l}35 \\
(72.9 \%)\end{array}$ & 48 \\
\hline
\end{tabular}

The table above table reveals that out of the 12 pupils in the control group for ability to sort pictures that look the same $7(58.3 \%)$ had mild difficulties sorting pictures that look the same while 5(41.7\%)still had severe difficulties. Also, for what makes them look the same $2(16.7 \%)$ had mild difficulties while $10(83.3 \%)$ still had severe difficulties identifying what makes the pictures the same. As for what makes them look different $2(16.7 \%)$ had mild difficulties identifying what makes the pictures look different while $10(83.3 \%)$ still had severe difficulties. More, so the identification of the missing features $2(16.7 \%)$ had mild difficulties while $10(83.3 \%)$ has severe difficulties. Then, the multiple response set reveals that $13(27.1 \%)$ had mild difficulties while $35(72.9 \%)$ still hag severe difficulties. 
International Journal of Trend in Scientific Research and Development (IJTSRD) ISSN: 2456-6470

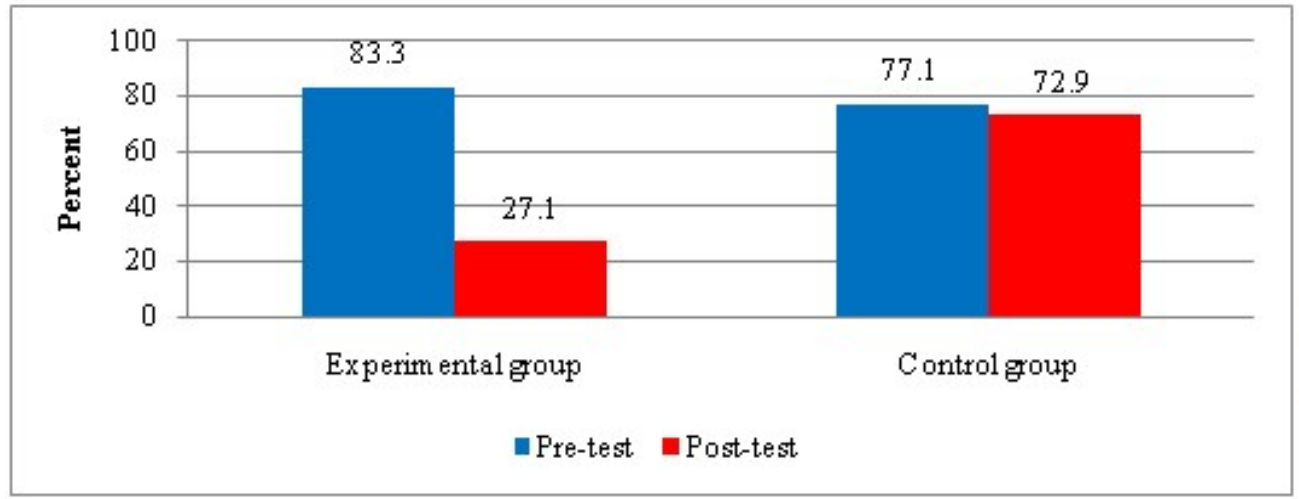

Experimental group: $\chi^{2}$-test: $\chi 2=8.22 ; \mathrm{df}=1 ; \mathrm{P}=0.004 ;$ Control group: $\chi 2$-test: $\chi 2=0.00 ; \mathrm{df}=1 ; \mathrm{P}=1.000$

Figure 26: Comparing Change in Disability Severity between Pre-Test and Post-Test and within Test Group for Ability to Work with Picture Images

In the experimental group, from pre-test to post test, it was realized that there was a significant drop from $83.3 \%$ to $27.1 \%(\chi 2$-test: $\mathrm{P}<0.05)$ in the proportion of children with severe disability. Unlike the experimental group, there was obviously no change in the control group though a slight decrease from $77.1 \%$ to $72.9 \%$ was observed but this was probably due to chance $(\chi 2$-test: $\mathrm{P}>0.05)$.

Table 37:Comparing Progression between Pre-Test and Post-Test for Ability to Work with Picture Images

\begin{tabular}{|c|c|c|c|c|c|}
\hline \multirow[t]{3}{*}{$\begin{array}{l}\text { Ability to Work with } \\
\text { Picture Images }\end{array}$} & \multicolumn{4}{|c|}{$\begin{array}{l}\text { Cumulative progression (in percentage of those with } \\
\text { positive change in score) }\end{array}$} & \multirow[t]{3}{*}{$\chi^{2}$-test } \\
\hline & \multicolumn{3}{|c|}{ Experimental Group } & $\begin{array}{l}\text { Control } \\
\text { Group }(\mathrm{N}=12)\end{array}$ & \\
\hline & $\begin{array}{l}\text { Pre-Test to } \\
\text { Formative }\end{array}$ & $\begin{array}{l}\text { Formative } \\
\text { to Post Test }\end{array}$ & $\begin{array}{l}\text { Pre-Test to } \\
\text { Post Test }\end{array}$ & $\begin{array}{l}\text { Pre-Test to } \\
\text { Post Test }\end{array}$ & \\
\hline $\begin{array}{l}\text { Sort out pictures that } \\
\text { look the same? }\end{array}$ & $\begin{array}{l}6 \\
(50.0 \%)\end{array}$ & $\begin{array}{l}3 \\
(25.0 \%)\end{array}$ & $\begin{array}{l}8 \\
(66.7 \%)\end{array}$ & $\begin{array}{l}4 \\
(33.3 \%)\end{array}$ & $\begin{array}{l}\chi 2=3.333 \\
\mathrm{P}=0.189\end{array}$ \\
\hline $\begin{array}{l}\text { What makes them } \\
\text { look the same? }\end{array}$ & 18 & $\begin{array}{l}7 \\
(58.3 \%)\end{array}$ & $\begin{array}{l}3 \\
(25.0 \%)\end{array}$ & $\begin{array}{l}1 \\
(8.3 \%)\end{array}$ & $\begin{array}{l}\chi 2=13.808 \\
P=0.001\end{array}$ \\
\hline $\begin{array}{l}\text { What makes them } \\
\text { look different? }\end{array}$ & $\begin{array}{l}3 \\
(25.0 \%)\end{array}$ & 4 & $\begin{array}{l}4 \\
(33.3 \%)\end{array}$ & $\begin{array}{l}0 \\
(0.0 \%)\end{array}$ & $\begin{array}{l}\chi 2=20.308 \\
P<0.001\end{array}$ \\
\hline $\begin{array}{l}\text { Identify the missing } \\
\text { features? }\end{array}$ & $\begin{array}{l}2 \\
(16.7 \%)\end{array}$ & $\begin{array}{l}4 \\
(33.3 \%) \\
\end{array}$ & $\begin{array}{l}3 \\
(25.0 \%)\end{array}$ & $\begin{array}{l}0 \\
(0.0 \%)\end{array}$ & $\begin{array}{l}\chi 2=16.778 \\
\mathrm{P}<0.001\end{array}$ \\
\hline $\begin{array}{l}\text { Aggregated } \\
\text { progression }\end{array}$ & $\begin{array}{l}12 \\
(25.0 \%)\end{array}$ & $\begin{array}{l}15 \\
(31.2 \%) \\
\end{array}$ & $\begin{array}{l}18 \\
(37.5 \%)\end{array}$ & 5 & $\begin{array}{l}\chi 2=13.897 \\
\mathrm{P}=0.001\end{array}$ \\
\hline
\end{tabular}

Data collected was analysed and compared then inferences were drawn.

The pre-test scores were compared with the $1^{\text {st }}$ formative test for each pupil. This was to enable the researcher to check for progression made by each pupil. Then, the scores of the first formative test were later compared with $2^{\text {nd }}$ formative test to check for progression. Later the pre-test and post-test results were compared and inferences drawn. 


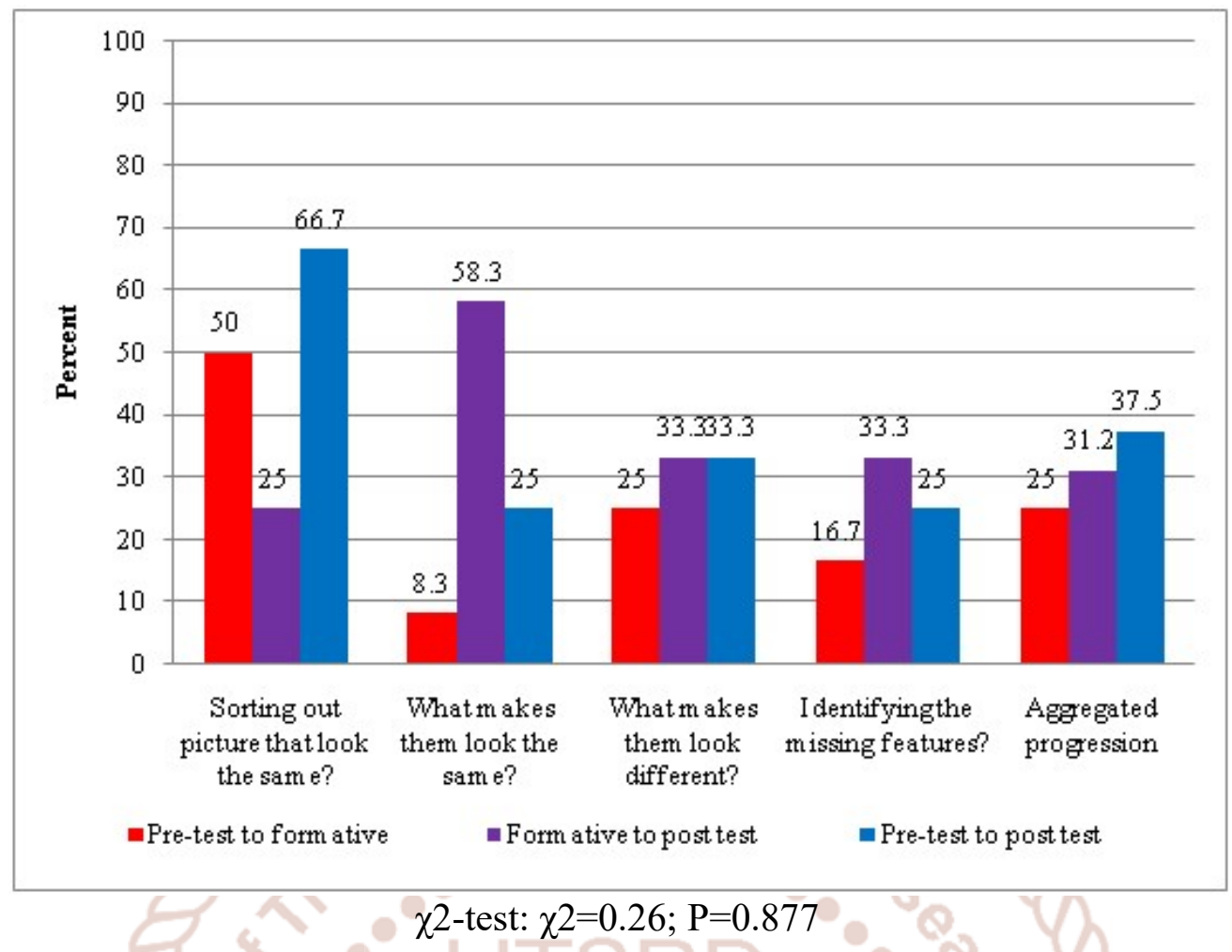

Figure 27:Change in Progression in the Experimental Group for Ability to Work with Picture Images

In aggregate, progression was weak. Though there was slight increased, progression was relatively constant ( $\chi 2$-test: $\chi 2=0.26 ; \mathrm{P}=0.877$ ) across test levels as it was $25.0 \%$ from pre-test to first formative, dropped slightly to $37.5 \%$ between first formative and post-test and was $20.8 \%$ from pre-test to post-test.

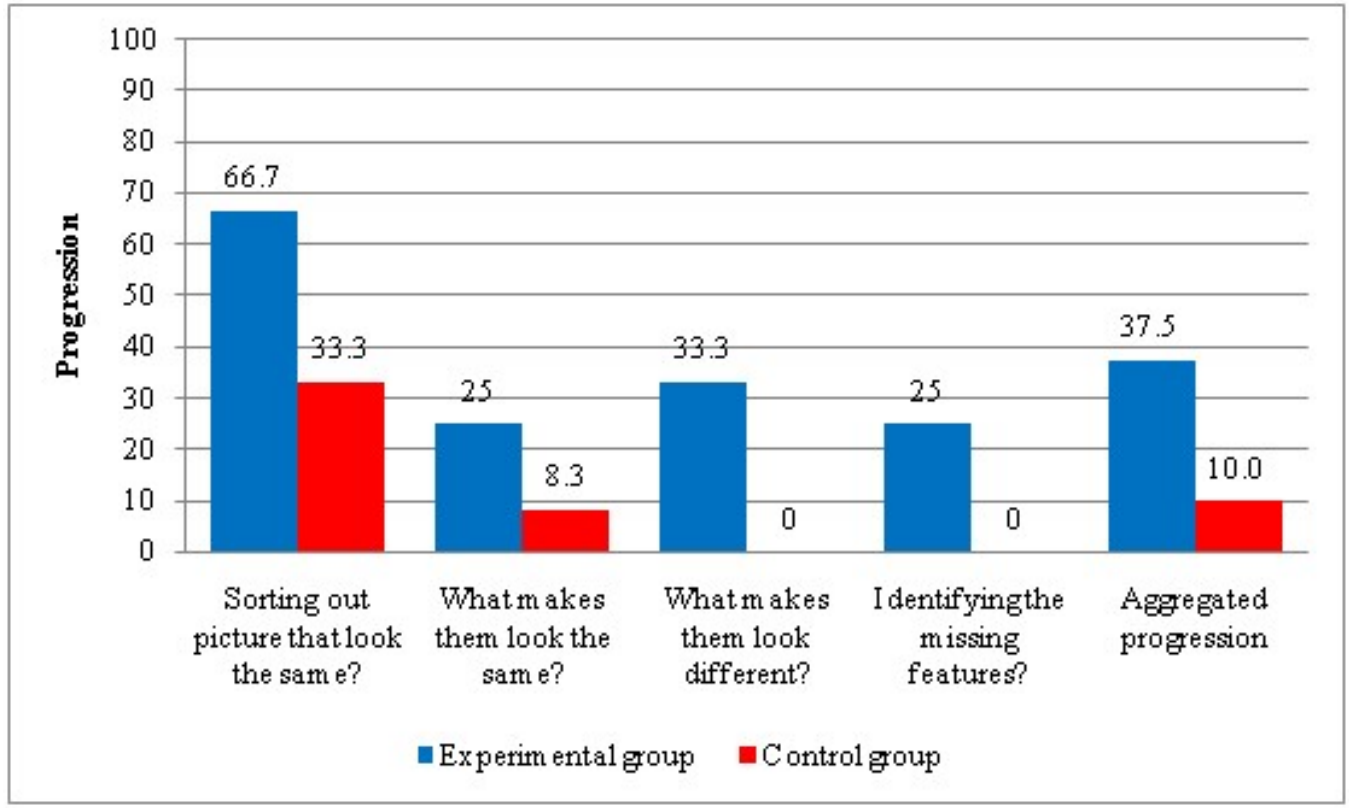

Figure 28: Comparing Progression between Experimental and Control Group for Ability to work with Picture Images

Comparing progression between control and experimental group, for ability to work with pictures for all the scales, progression was higher in the experimental group and in aggregate it was $37.5 \%$ in the experimental group as against $10.0 \%$ in the control group and this discrepancy was significant $(\chi 2$-test: $\mathrm{P}<0.05)$.

This research hypothesis was out to confirm or reject if visual discrimination training on the recognition of pictures has any effect on reading among struggling 
readers in primary five. Four items were examined in all scales. Similarities in pictures, differentiation in pictures, missing features in picture, similarities between specified items in the pictures in all scales. Comparing the progression between the experimental and control groups, it was revealed that the experimental group had a higher progression because it received the treatment exercise. The experimental group had a positive progression in all scales at $37.5 \%$ as against $10.0 \%$ in the control group. This implies that visual discrimination training on the recognition of pictures has a positive effect on reading among struggling readers in the experimental group. Therefore, we reject the null hypothesis and retain the alternative that states that visual discrimination training on the recognition of pictures has aneffect on reading among struggling readers in primary five in Buea municipality.

Also, comparing the analysis for the interview conducted withpupils on the difficulties that struggling readers face with reading pictures, some interesting information was revealed. That out of the 24 pupils who were interviewed in relation to their ability to recognise similarities in pictures presented, 9 of them said the colour and actions make them similar while12 of them said the characters and 3 of them said shapes. This implies that 15 of them did not see the similarities. Regarding what makes them different 9 of them said the three head and two heads while 5 said the blue and green colour and 10 of them said the men are 3 which implies that cumulatively 15 of them did not see the difference. Besides when asked about the missing feature in the picture 14 of them said the cap while 3 said the men and then 7 said the head. Implicitly 17 of them could not identify the missing feature. As regards to the similarities and differences in the specified pictures 7 said both pictures carry the images of three men while 10 said in both pictures the men are soldiers and then 7 of them said there are no similarity. This also proves that 14 of 24 them did not notice the similarities between the pictures. Implying that struggling readers have a deficit in visual discrimination skills for the recognition and reading of pictures,

The thematic analyses for the psychological item alsoreveals some important information about struggling readers that if reflected upon can help in meeting the needs of struggling readers in primary five as follows; Struggling readers have visual discrimination deficit which cause them to read with errors. This view was supported by Stein and Walsh (1997) in their magnocellular deficit theory of dyslexia, that struggling readers have difficulties transmitting visual impulses through the eyes to the brain due to a deficiency in omaga 3 and 6 fatty acid which are essential fats that helps in the proper functioning of the brain. In articulating this view, Snowling (2001) holds that such readers have reduced ability to detect coarse details but a normal ability to detect fine details. They stress that there tend to be a prolonged persistence of visual images causing masking on vision on successive fixation. And that this causes their reading to be fraught with errors of reversal, omission, repetition and constant stops and starts. They argue that to help struggling readers read, it is necessary to provide them with repeated instruction over time. However, this recommendation is contrasted by this present study in that, it emphasizes the need to provide struggling readers with repeated instruction without stressing on the need for assessment to determine why some children struggle with reading. The study therefore improves upon the recommendations of Stein and Walsh in their magnocellular deficit theory of dyslexia adding that it is important to assess struggling readers to determine why they struggle with reading so as to provide them with the appropriate instruction that will suit their specific reading needs.

More so, struggling readers expressed the desire to learn how to read and write. This view was supported by Erikson's theory of psychosocial development (1950), that between the ages of 6-13years, children enter primary school enthusiastic to learn and that if they are not properly guided, they develop a sense of inferiority, become unproductive and incompetent. In line with this view, Tchombe (2011) articulates Erikson's theory of psychosocial development that primary school children 6-13 years are between the crisis zone of industry and inferiority, willing to cooperate and share capable of recognising cultural and individual differences. She argues that when struggling readers perform poorly and are ridiculed this helps to limit their chances of social interaction through which they can learn. She stresses that, teachers and parents should stop ridiculing struggling readers but rather provide them with more opportunities to practise to develop skills in reading.

Besides, struggling readers are capable of learning. They require that their teachers and parents should encourage them by modelling reading lessons so that 
they can repeat after them and they will gradually be able to learn. This view is supported by Vygotsky's theory in his theory of social constructivism (1920). He stresses that, learning takes place in the zone of the brain called the zone of proximal development with a lower and upper limit. He argues that within the lower limit of the brain, children are capable of learning information that is necessary for survival. But that, to learn concepts facts and complex skills that occur in the upper limit of the zone of proximal development, they need to be modelled by a more skill persons through the process of scaffolding. This is a situation where a more skilled person models the reading lesson or skills to be learnt and gradually reduces the support provided as soon as the learner begins to master the skill. This implies that when teachers and parents provide struggling readers with modelled reading experiences this will help them to be able to read with time.

Furthermore, teachers are ignorant of the strategies that could be used to teach reading. They are ignorant of the role of active participation in teaching and learning. They fail to allow the pupils actively participate in producing instructional aids that will help them quickly recognise similarities and differences in the items they produce. For example, sentence cards, letter cards, number card, maps, picture card just to name a few. They could give them group tasks individual tasks and assignments and encourage them to exhibit the finished product in class for some time. That is why they focus all their attention on readers. Knowing that as teachers they could create many opportunities to help children learn how to read with explicit individualised support without trying to compare performance and without limiting their teaching of reading to "English" lessons and reader will help them a great deal. This view is supported by Marling and Paugh (2004) that struggling readers need intensive, explicit and individualised support and direction that must be provided by their teachers if they must develop skills in reading. They stress that teachers should create structures that will enable them provide struggling readers with individualised support. To buttress this point Torgessenet al (2007), hold that reading teachers must work with small groups of identified learners who have difficulties with instructional needs so as to reach the individual needs.

Also, findings reveal that teachers are ignorant of their role to motivate the children so as to create opportunities for the development of skills and competence that will help them receive recognition from their parents, teachers and peers. In articulating this view Nwazuoke (2000) reiterates that the classroom teacher is a significant person in the life of the children to help them succeed in school. He argues that if teachers do not have sufficient professional training, it becomes difficult to be able to help the children. To buttress this point, Yuh (2014) argues that regular teacher scan play a crucial role in reducing discrimination in school by including all children in the teaching and learning process. She recommends that schools today should make an effort to provide inclusion for children with disabilities, by encouraging regular classroom teachers to participate actively in the successful implementation of inclusive practices.

Besides, teachers are ignorant of the cultural and socio-economic realities of their environment. Many African countries Cameroon inclusive; have very large families because of their polygamous practices. This makes it quite difficult for parents to provide the basic needs for their children. Besides, some of these parents are illiterates and cannot help their children at home. Therefore, the children look up to their teachers to help them learn how to read. Even some of the literate parents because of the socio-economic situation of the country cannot find time to teach their children at home due to their busy schedules in search for wealth. Also due to the large class size the government and the councils concerned cannot provide reading materials for all the children in the municipality. They can also not provide computer and software programmes for individualised teaching and libraries to nurture the reading culture in children. Reading Rocket (2011) holds that learners come from varied background and with varied experiences supports this view. They argue that teachers are supposed to know this in order to nurture in the children reading competence. They emphasize that some children acquire reading skills with ease because of their early exposure to reading while other do not because of the lack of background experience from home.

According to Gambrel and Presley (2003) in teaching struggling readers, teachers should understand how to teach reading so that they can adapt their learning environment, instructional materials and teaching strategies to suit the particular needs of the learners in their particular environment. Therefore, it is necessary 
for the teachers to understand the socio-cultural setting of their environment and to plan their lessons to suit the needs of their learners using locally made teaching aids to provide pupils with a literacy enriched classroom environment. They could ask the children to bring salvage material that could be used to prepare word cards, donate words, prepare vocabulary list, sentence cards, number cards sentence cards and many more during arts and craft lessons or give them as home work. When this articles made by the children are displayed in class and their attention is drawn to them daily, it will help to reinforce the lessons taught, motivate struggling readers to read, and also provide them with an opportunity to practice reading even when their parents cannot afford readers. To buttress this point Burns et al(1996)argues that many English words are not spelled the way they sound and that children need to recognise them on sight words as a whole configuration to ease reading. This helps to nurture the culture of reading and to encourage a positive attitude towards reading.

Again, teachers are ignorant of the effect of the classroom climate on the learners. The classroom environment and the classroom climate affect the learners differently based on their disabilities and home backgrounds. While some learners are favoured and motivated to learn, some of their peers are unable to learn for varied reasons like labelling, exclusion and other psychological problems from home. This attacks their self-esteem causing them to exhibit varied undesirable behaviours. This view is supported by Garnett, (2010) that classroom conditions can affect some children especially those from poor homes, those with attention deficit, those with learning disabilities who are the most vulnerable in inclusive classrooms. He stresses that teachers ought to create a conducive learning environment by not labelling struggling readers and also give them the opportunities to interact with their teachers and their peers. This view is articulated by Tchombe (2011) that when struggling readers are ridiculed and excluded in the learning to read process this helps to limit their chances of social interaction through which they learn. To buttress this point, Sabornie and Kauffman (1986) as in Heward (2003) holds that struggling readers enjoy socially rewarding experiences in inclusive classrooms that will depend on the social climate created by the teachers, peers and parents and others with whom pupils with disabilities interact.
Furthermore, the instructional materials werepoorly used to serve the needs of the struggling readers. Field observations reveal that the instructional materials like number cards, word cards, letter cards, sentence cards just to name a few are briefly introduced to the learners during the lesson without enough time to exploit them. Shortly after they are introduced they are taken away without proper knowledge on how they could be used to encourage social interaction between the pupils and their peers to encourage the mentor- mentee relationship in the classroom. In articulating this view Burnset al (1996) holds that reading instruction could be improved by using instructional materials that can enhance sight word recognition. They argue that children can acquire sight word without analysing them when they frequently see them. They emphasize that when such materials are exposed, they will help struggling readers to practice reading and also nurture the reading culture in all the children. Such material will serve them to provide the repeated instruction that they desire through peer tutoring during interaction.

Teachers are ignorant of how to evaluate struggling readers in their classrooms. Interview with the teachers revealed that they could only identify struggling readers in their classes when they are called up to read. This implies that since it is not possible to call up every child in class to read, some of the children who struggle with reading may not be noticed by the teachers. They may only be noticed when they fail inthe examination but are eventually promoted to the next class due to the policy of mass promotion. According to Torgessen, Houston, Rissman and Kosanavich (2007), children's performance data should be used to guide instruction and allocate instructional resources. They emphasize that teachers should use valid and reliable assessment to check reading progress that will provide key information that will help the teacher adapt reading instruction to suit learner's needs. To buttress this point Burnset al (1996), contend that struggling readers need opportunities to develop a positive attitude towards reading and to build a positive selfesteem. This implies that parents and teachers should take interest in the education of their children who are struggling with reading to encourage and motivate them rather than ridicule, discourage and neglect them. The children expect them to model reading lesson for them, get specialist teachers to teach them or sent them to attend remedial classes. Therefore, parent ought to dialogue with their children to 
understand their difficulties with schooling rather than labelling and ridiculing them because they cannot read. This is supported by Reading Rocket (2011)that it necessary for parent and teachers to have a basic idea about what it takes for a child to read, how the child can be taught how to read, to how to motivate the children to read, to be able to help their children struggling with reading. They argue that this knowledge will help them to better appreciate the importance of reading, how to motivate their children to read, plan reading instruction for them and also choose the appropriate teaching strategies and instructional materials to suit their needs.

From the analysis of these findings, it is evident that struggling readers in primary five are often frustrated in the classroom. Such frustration can cause them exhibit varied undesirable behaviours at home, in school and in the community. According to Ryan (2004), struggling readers often suffer a frustration that is centred around their inability to meet the expectations of their teachers and parents which causes them to develop a perfectionist expectation in order to deal with their anxiety. When they are labelled and excluded over time they develop coping strategies that are often reflected negatively in their undesirable behaviours. For example, cheating, during examinations, absenteeism, truancy, school dropout, lies telling, just to name a few causing some children to graduate and go back home the way they entered school. This view is supported by Tambo (2003) that the government of Cameroon experiences educational wastage when some pupils drop out of school because they cannot cope with experience in the classroom. To further support this view some participants admitted that they loved to be promoted even if they cannot read so to graduates and leave school to do business.

This situation could have been redressed if the local realities and the cultural and socio-economic situation of the country were taken into consideration to guide the curriculum and implementation policies. Understanding that most families are large including dependants from the extended families most parent cannot provide all children with textbooks, that all children cannot be taught by their parents at home or even have an enabling environment to study at home to permit them study at home could guide thecurri culumand implementation policies for better results.

However, the observation of the classroom conditions and pedagogic practices in primary schools in Buea municipality suggest that there may be a complete neglect of struggling readers in primary school in Buea municipality in Cameroon. The teachers based their mind on the provision of class reader to teach reading without trying to identify why some children struggle with reading. According to reading rocket (2011), it is necessary for parents and teachers to know why some children struggle with reading so that they can provide them with the appropriate instruction. They stress that this knowledge will help them better appreciate the ability to read, choose the appropriate teaching learning materials that will lead to success. This implies that the achievement of success in school depend largely on parents and teachers. This raises the issue of the quality of training for basic education teachers and that of their trainers.

It is worth noting here that, though there is a text signed by the President of the Republic of Cameroon, Biya(2010) in favour of persons living with disability, and those at risks of being marginalised, there is no text of application. There is therefore the need to revisit curriculum and implementation policies and practices that will benefit all the children in the classroom irrespective of their status. Parents send their children to school to learn how to read and write, but when these children return home without being able to read and write, it is quite frustrating to the individual, his or her family, the educational system and the larger community. These and many other weaknesses cannot permit us reach the goals of "vision 2035" to empower our citizens to become entrepreneurs. Therefore, it is necessary to address these issues to reduce crimes, street children and a high level of over dependence on foreign experts to handle major projects in Cameroon.

Inferences from the findings reveal that struggling readers in primary five are not giving the necessary attention in the classroom. According to Kelly and Campbell (2012), to effectively teach struggling readers to be able to read, emphases should not be placed on teaching method only, but rather on teachers' attitude, teachers' knowledge on reading, use of instructional materials and continuous professional development and skills. They stress that struggling readers will make more progress if they are taught by committed and informed teachers. Therefore, teachers must not only be able to identify struggling readers in their classroom, but should be able to provide them with the appropriate instruction so that they can read. This will provide them with the opportunity to 
participate in the classroom reading activities to help them beat their perfectionist expectations.

To fully address some issues that can improve the reading skills of struggling readers in primary schools in the Buea municipality and by extension Cameroon, there is need to revisit the following areas:

Teacher quality in terms of training and professional development.

$>$ Considering the development of the reading assessment tool to determine why some children keep struggling with reading despite the efforts made.

$>$ Attitude change for teachers and parents.

$>$ The provision of literacy enriched classrooms to reinforce sight word recognition.

$>$ This study was able to identify areas that could be explore as follows

$>$ To reinforce the implementation policy for inclusive practices in schools in Cameroon through regular inspections.

$>$ To improve on the pedagogic skills of teachers in the field to empower them with skills to handle inclusive classrooms.

$>$ To reintroduce special pedagogy in primary teacher training colleges so that teachers graduate having the skills to teach special needs learners in inclusive classrooms.

Findings from observations in the field together with facts gathered from the analysed data reveal that visual discrimination training in the recognition of letters, words, numbers, geometric shapes and pictures have a positive effect on reading among struggling readers in primary schools within the Buea municipality

\section{Implications of the research to education}

This study has brought to the lamplight some important contextual information about how theories guide practice in the field of education in order to cope with issues of diversity in learners for the development of a healthy personality.

The study therefore adds more knowledge to the magnocellular deficit theory of dyslexia by stressing that it is necessary to assess struggling readers before providing them with the appropriates repeated instruction. This implies that if teachers can identify that a particular learner has visual discrimination deficit through assessment this will help them provide the child with the appropriate instruction that will meet the specific needs of the learner.

Also, it highlights the need for attitude change on the part of teachers and parents to encourage children learn irrespective of their status learn irrespective of the status.

Besides, it touches on the pedagogic competences of Basic education teachers to imbibe new strategies of enriching classroom environment to meet the needs of all learners in their classrooms.

Also, it addresses teachers of Basic education and parents of struggling readers by providing information about the reading process, characteristics of struggling readers their needs and desires and how they could be handled to enable them read and develop a healthy personality.

More so, it raises the issue of inadequate training and professional development for teachers at both initial and in -service levels with respect to the production of instructional materials using salvage materials. There is enough evidence from the data collected to illustrate that struggling readers arenot given the necessary support they deserve in our primary schools. If the recommendations of this study are implemented some benefits will be realised that will lead to Psychological satisfaction for the learners, their families, the educational system and the larger community.

Furthermore, this study highlights the need for improvement on the training programme for teacher trainers include more of a practical approach in teaching in order to be more preformat. It calls on policy makers to introduce courses on how to prepare instructional materials at the level of Higher Teachers' Training Colleges to give graduates more skills. This will empower them with skills that they will eventually transfer to their trainee. Such practices will help Teacher Training Institutions to function as workshop centres for the production of instructional materials that will suit the different groups of learners. In this way, student teachers will also acquire skill to take to the field to be able to teach effectively. This will go a long way to improve pedagogic practices and the achievement of teaching and learning goals in primary schools. 
More so, it reminds teachers and parents on how children acquire skills in reading so that they can better prepare their children for schooling. This will help them provide their children with enriching literacy environment to nurture reading

Furthermore, it tickles the minds of administrators and policy makers to reflect on the need to provide struggling readers with early intervention programs that will help nurture in the learners a reading culture.

Parent and teachers will know from this study that when struggling readers are excluded and ridiculed in the learning to read process it limits their potentials by causing them to consider themselves as failures. Issues raised in this study will guide policy makers and administrators to make sound judgment and take decisions that will suit our culture and environment. Therefore, it is necessary to encourage and motivate struggling readers in our primary schools. In this way, more children will be able to develop their full potentials and become experts in their different areas based on their talent and aptitude.

\section{Major Contribution of the Study}

This study has helped in answering the research questions with proofs that visual discrimination on the recognition of letters, words, numbers, geometric shapes and picture items have a positive effect on reading among struggling readers in primary five in Buea municipality.

$>$ It has also led to the improvement of the magnocellular deficit theory of dyslexia by Stein and Walsh (1997) by adding that, it is necessary to assess struggling readers to determine the exact cause of the reading difficulties so as to provide the appropriate repeated instruction.

$>$ Also, it fills the existing gap in literature by providing relevant information on the need for assessment to guide instruction for struggling readers.

$>$ More so, it highlights the need for the development of an assessment instrument to be able to determine the exact cause of the reading difficulties experienced by some children in schools in Cameroon.

\section{Recommendations}

The general objective of this study was to investigate the effect of visual discrimination training in the recognition of items (letters, words, numbers, geometric shapes and pictures) on reading among struggling readers in primary five in the Buea municipality in Cameroon. Based on the findings the following recommendations were made to the following group of persons:

\section{Teachers}

$>$ Visual discrimination training on the recognition of letters, words, numbers, geometric shapes and pictures could be reinforced in all classes in primary school. In these ways, pupils who were not able to master the concepts earlier will be given the opportunity to do so.

$>$ Teachers could change their attitude towards struggling reads by focusing on the learners' strength and not on their weaknesses to motivate, them learn rather than discourage them from learning.

Reading lessons could be modelled to struggling readers to serve as a guide rather asking them to read by themselves

Teachers could endeavour to identify why some children struggle with reading, and to provide small group instruction that will suit their needs.

\section{Parents:}

They could take interest in the education of their children who are struggling with reading because such children need their support to be able to develop skills in reading. They could create time to dialogue with their children to know the difficulties they face with their schoolwork.

Parents could learn to contribute didactic materials to school that will help the teachers teach their children better.

They should provide struggling readers more opportunity to read by labelling object at home especially in their rooms rather than engaging them more in house chores.

\section{Head Teacher:}

$>$ They could encourage teachers to enrich their classroom with literacy materials to help develop sight word recognition and to nurture the reading culture in the children.

$>$ They could create reading clubs in schools and award prizes to motivate both teachers and the pupils to take the reading exercise serious.

\section{Pedagogic Inspectors:}

They could organise seminars for the teaching of exceptional children in inclusive classrooms to equip 
the teachers in the field with skills to cope with the current pedagogic trends.

\section{Curriculum Planners:}

$>$ They could enrich the curriculum of teacher trainers not only with didactics of teaching specific subject but also didactic of teaching exceptional children in inclusive classrooms.

\section{Policy Makers:}

$>$ They should consider the introduction of early intervention programs in the Basic Education sector to develop the full potentials of the learners. This will help to reduce school dropout, street children, high crime wave and financial wastage on education, develop the full potential of learners and to nurture a community of people with a healthy personality.

\section{REFERENCES}

1. America Psychological Association, (2016). Reading instruction changes the brain. Retrieved on July $8^{\text {th }} \quad 2014$ at 7.20am fromwww.apa.orglaction\resources \research-inaction $\backslash$ reading. apsa.

2. Amin, M. E. (2005). Social science research: Conception, methodology and analysis. Kampala: Makerere University Printery.

3. Arky, B.(2014).Understanding visual processing issues. Retrieved on June $14^{\text {th }} 2015$ at 7.30 amfrom https://www.understood.org/en/learning-attentionissues/child-learning-disabilities/visual

processing. Understanding Visual Processing Issues.

4. Breakwell, G. M., Hammond, S.andFiffe-Schaw, C. (2004).Research methods in psychology. London: Sage Publications.

5. Burns, P. C, Roe, B.D. and Ross,E. P. (1996). Teaching reading in today's elementary school. $7^{\text {th }}$ Ed. Boston: Houghton Mifflin.

6. Burroughs, R. (2014). Simple Visual Discrimination Training for a Child with Autism and Exceptional Learning Difficulties (2014).Honours Theses. Paper 2512, Western Michigan University. Retrieved on July $8^{\text {th }} 2016$ at

7.40amfrom http://scholarworks.wmich.edu/honors theses.

7. Chard, D.J. and Osborn, J. (2015).Phonemics and word recognition instruction in early reading programmes. Guidelines for accessibility: Reading rocket. Retrieved on July $8^{\text {th }} 2015$ at 8.20 am from www.reading rockets.org $\backslash$ article/phonics-andword recognition-early reading programesguideline-accessibility.

8. Christensen, C., Horns, M. and Johnson, C.(2010). Disrupting class: How disruptive innovations will change the way the world learns. Boston: McGraw Hills Companies.

9. Clutten, S.C. (2009). The development of visual perception test for learners in the foundation phase. Retrieved on April $12^{\text {th }} 2014$ at 9.20amfromuir.unisa.ac.za/bitstream/handle/1050 0/2613/thesis_clutten_s.pdf?

10. Cohen, L., Manion, L. and Morrison, K.(2007). Research Methods in Education. London and New York: Routledge

11. Cusimance, A. (2007). Visual discrimination: Noting differences in frequently misperceived words. Retrieved on July $26^{\text {th }} 2014$ at 7.30 amfrom www.amazon.com/usual/ discrimination differences frequently - misperceived /dp/0972776222.

12. Dauksas, L. and White, J. (2008).Discovering shapes in Pre-school. Teaching Young Childern.Vol.7 No.4Retrieved on July $8^{\text {th }} 2014$ at 9.20am from www.naeyc.org/tyc/article/shapesspace.

13. Ehri, L. C.,Nunes,S. R.and Willows,D.M. (2001).Systematic phonemic instruction helps students learn to read: Evidence from the national reading pane's meta-Analysis. Education research, 71 (3), 393-447

14. Erikson, E. (1950). Childhood and society. New York: Morton. Retrieved on March $8^{\text {th }} 2015$ at 7.20amfrom www.amazon.com / Childhood Society -Eric- H- Erikson / dp/ 039331068 X.

15. Fraenkel, J.R. andWallen, N.E. (2006). How to design and evaluate research in education. New York: McGraw-Hill Companies.

16. Gagne, M.B. (2007). Skills necessary for proficient reading. National reading panels. Teaching Children to Read. Retrieved on July $8^{\text {th }}$ 2015 at 7.50amfrom www.nationalreachingpanel.org/ publications/summary.htm

17. Gall, M. D., Gall, J. P. and Borg, W. R. (2015). Applying Educational Research: How To Read, Do, and Use Research To Solve Problems of Practice, Loose-Leaf Version with Marketing Brochure CY2015, 7th Edition. New York: Longman. 
18. Gambrel, L. B. and Pressley, M. (2003). Effective reading instruction. Retrieved on October $14^{\text {th }}$ 2015 at 6.30amfrom https://www.pearsonhighered.com/assets/Hip-UsPearhighered/Simple-Chapter/0132963507.pdf.

19. Gangwer, T.(2010).Visual discrimination: Visual teaching alliance. Retrieved on February $20^{\text {th }} 2015$ at 7.00amfrom www.online.org.article 19296.

20. Garnette, K. (2010). What are classrooms like for students with learning disabilities. Retrieved on October $14^{\text {th }} \quad 2015$ at 4.30amfrom w.w.w.readingrockets, org/Article/What-areclassrooms-students-learning-disabilities.

21. Heward,W.L. (2003). Struggling readers: What consultants needs to know. Journal of educational and Psychological, consultation 15(2) 191204.Retrieved on July $8^{\text {th }} 2014$ at $7.20 \mathrm{am}$ fromhttp:www.readinggate.net ljournal $\backslash 10474412 . j$ ournal of educational and psychological consultation.

22. Hoss, V. (2014). Importance of reading skills. International news. Retrieved on February $24^{\text {th }}$ 2015 at 7.20amfrom http:/ everyday life. Global Post. Com/Importance.

23. Hundt,K., (2013). Reading and reVisual discrimination: Breakthrough in learning blog. Retrieved on April 14 2016 at 9.30am from w.w.w.get breakthrough.com $\backslash$ blog $\backslash$ bid $\mid 293058 \backslash$ reading-andvisual discrimination.

24. Hurst, M. (2003). Theory of cognitive development. Retrieved on February $24^{\text {th }} 2015$ at 8.50amfrom study. Com/ academy/ lesson/levvygotsky's-theory -of - cognitive development.htm/.

25. Ihenacho, I. J. (2010). Inclusive education in higher education: A keynote address on the investiture of the UNESCO Chair at the University of BUEA, Cameroon, 26 May, 2010.

26. Ihenacho,I. J.(1998).Reading readiness diagnostic test instrument: Department of special education and rehabilitation sciences. University of Jos.

27. Kelly, C. and Campbell, L.(2012).Helping struggling readers. Retrieved on April $20^{\text {th }} 2015$ at 10.00amfrom education.jhu.edu/pd/newhorizonsstrategies/topics /literacyarticles/helpingstrugglingreaders.

28. Kurtz, L. A. and Net Library (2006). Visual perception problems on children with $\mathrm{AD} / \mathrm{HD}$, autism and other learning disabilities. A guide for parents and professionals. London. Jessica Kingsley Publisher. Retrieved on April $24^{\text {th }} 2015$ at

9.10amfromwww.sydney.edu.au/compass/docume nts/visual-discrimination-facts.pdf.

29. Lake, W. S., Eskridge, D. and Perry,L.(2000).Reading the cornerstone to success. Retrieved on April $23^{\text {rd }} 2015$ at $10.10 \mathrm{am}$ from www Learning disabilities-readingtutor.com|reading process.htm|.

30. Laurice, J (2002). Best practices in planning interventions for students with reading problems. Retrieved on July $8^{\text {th }} 2014$ at 7.20am from www.readingrockets.org $\backslash$ article $\backslash$ best-practicesplanning-interventions-students-reading-problems.

31. Laurice, J. (2004). Reading: Encouraging positive attitudes: Strategies for parents and teachers. Ohio: Ohio State University

32. Law No $2010 / 002$ of $13 / 4 / 2010$ Relating to the protection and welfare of persons with disabilities

33. Marling, C. D. andPaugh, P. (2004).A classroom teacher's guide to struggling readers. Retrieved on June rrn $^{2} 26^{\text {th }} \quad 2014$ at $8.20 \mathrm{am}$ fromhttp://books.google.cm/bookd/about/A_classr oom-Teachers-s-Guide-to struggling readers.htm/?id=WGCQAQAAMAAJ`redir-esc $=$.

34. Mcleod, S.B. (2007). Simple psychology. Retrieved on July $14^{\text {th }} 2014$ at 8.00 amfrom www. Simple psychology. Org/vygotsky.htm/.

35. McMillan, J. H. (1996). Educational Research. Fundaments for the consumer. Harper Collins College Publisher: New York.

36. Moats, L. andTolman,C. (2009). Reaching disabilities. Retrieved on July $24^{\text {th }} 2014$ at 8.30amfrom www.reading rockets.org/article. 28749.

37. Morrow, L. M. Gambrel,L.B. and Pressley, M. (2003). Best Practices in literacy instruction. New York:The Guilford press.

38. Nana,C. (2015). Research methods and applied statistics: Beginners and advanced learners. Buea: GOOAHEAD.

39. National Centre for Learning Disability (2013). Thepower of hope to learn and succeed. Retrieved on June $26^{\mathrm{h}} \quad 2014$ at 8.00amfrom www.ncld.org/types-learning - destabilizes/ auldrelated -issues/visual-processing- disorder/ on 26/6/2014.

40. National Institute of Child Health and Human Development (NICHHD) (2007).Report of the 
International Journal of Trend in Scientific Research and Development (IJTSRD) ISSN: 2456-6470

National Reading Panel.Teaching children to read. An evidence based assessment of scientific research literature on reading and its implications for reading instruction.Report on subgroup (NIH) no 00-4769. Washington, D.C:Government.

41. Nsamenang, A. B., Tchombe, T.M.S.,Kelller, H. and Fulop, M. (2013). Across- cultural psychology: An Africentric perspectives. Limbe: Design House.

42. Nsamenang, A.B. and Tchombe, T.M.S. (2011). Handbook of African educational theories and practices, A Generative Teacher Education Curriculum. Yaounde: Presses Universitairesd'Afrique

43. Nunan,D. (2003).Practical English Language Teaching. Boston:McGraw Hill companies.

44. Nwazuoke,I. A. (2000).Professional Preparation of Teachers of Exceptional Children forInclusive Contexts. The Exception Child, 4 (1), 34-35.

45. OT Mom Learning (2009) Visual discrimination activities. Retrieved on December $24^{\text {th }} 2014$ at 9.00amfrom www.ot.mom.learningactivities.htm/--specificdelaysymptoms.

46. Patino, E. (2017). Types of test for reading, writing and Math. Understood for learning and attention issues. Retrieved on July $8^{\text {th }} 2014$ at 7.20am from www.understood.org/en/schoollearning/evaluations/types-of-test/types-of-testfor-reader-writing and maths.

47. Pearson Education (2014).Pearson integrated HSM common core correlations. Retrieved on July $8^{\text {th }} \quad 2014$ at $7.20 \mathrm{am}$ from www.Pearsonschool.com/..Pearson\%20 integrated $\% 20 \mathrm{HSM} \%$

48. Picciano, A. (2017). Educational Research Primer (Continuum Research Methods). Retrieved on July $8^{\text {th }} \quad 2015$ at $7.20 \mathrm{am}$ from http://www.anthronypicciano.com/sampling/htlm/

49. Pyschohawks (2010). Theories of Cognitive Development: Lev Vygotsky. Retrieved on July $14^{\text {th }} 2014 \quad$ at 9.30 amfrom https: \psychohawks:wordpress.com/2010/09/05/t heories-of-cognitive-dev'tlev-vygotsky.

50. Renee, T.(2013).Visual discrimination: The role of visual discrimination on reading and writing.Retrieved on July $23^{\text {rd }} 2014$ at 8.10amfrom www.schoolsparks. com/take-agoodlook.tipsforhoningvisualdiscrimination.

51. Renee,T(2013). Early childhood development and visual discrimination skills. Retrieved on July $26^{\text {th }}$
2014 at

8.15 amfrom

www.schoolsparks.com/early-childhooddevelopment/visual discrimination.

52. Rongione, D. (2000).Problems with number recognition kindergarten.e-how-contributor. Retrieved on July $8^{\text {th }} 2014$ at 7.20 am from http:\www.e-how.com $\backslash$ info.8340197 \problemnumber-recognitio-kindergarten.html.

53. Ryan, M. (2004). Social and emotional problems related to dyslexia. Retrieved on February $20^{\text {th }}$ 2015 at 8.00amfrom www.don/ine.org/article/19296.

54. Sceniak, M. P., Chatterjee, S. and Callaway, E. M. (2006). Visual spatial summation in macaquegeniculocortial afferents. Journal of neurophysiology, $96 \quad$ (6),3474-3484: Dol:10.1152/Jn.00734.2006.

55. Shadish, W.E., Cook, T. D.and Campbell, D.T. (2002).Experimental and quasi-experimental designs for generalised casual inference. New York: Houghton Mifflin Company.

56. Shillcock, T.J. and Scott, M. (2015). Magnocellular pathway. Advanced vision. Retrieved on February $14^{\text {th }} 2015$ at 9.20amfrom www.advancedvisiontherapycentre.con/service/as sessments/neuro-optometric-

assessment/magnocellular pathway on 14 / 2/ 2015.

57. Shuttleworth, M. (2008).Quasi-experimental design.Retrieved on November $12^{\text {th }} 2014$ at 9.10amfrom Explorable.com: https://explorable.com/quasi-experimental-design.

58. Singleton, C and Henderson L. M.(2006).Visual factors in reading. London Review of Education, 4 (1), 89-98.

59. Skottum, B.C (2000). The magnocellular deficit theory of Dyslexia; The evidence from contrast sensitivity. Vision Research, 40 (1) 111-127.

60. Skottun, B.C (2010). On the conflicting support for magnocellular deficit theory of dyslexia. Trends in Cognitive Science, 4 (6)211-212.

61. Smith, D. D. and Tyler, N.C. (2010). Introduction to special education: Making a difference. Library of Congress Cataloguing - U.S.A. Publication data.

62. Snowling,M. J and Hulme, C.J. (2006). The Science of reading handbook. Oxford: Blackwell.

63. Snowling, M. J. (2001). From language to reading and dyslexia. Retrieved on May $23^{\text {rd }} 2015$ at 
International Journal of Trend in Scientific Research and Development (IJTSRD) ISSN: 2456-6470

\subsection{0amfrom}

onlinelibrary.wiley.com/doil10/002dys. 85 .

64. Stein,J. and Walsh, V. (1997).The Magnocellular deficit theory. Retrieved on June $13^{\text {th }} 2014$ at 10.00amfrom

http://www.2020true.com/office/box-

b/documents.

65. Stein, J. and Walsh, V. (1997). To see but not to read. The magnocellular theoryof Dyslexia. Trends in Neuroscience, 20(4)147 - 152.

66. Stein, J. (2001). The magnocelluar deficit theory of developmental dyslexia Jan- Mar;7 (1): 12-36. Retrieved on July $14^{\text {th }} 2014$ at $7.20 \mathrm{am}$. www.pubmedpmid;11305228.

67. Stein J. (2014).Dyslexia: The role of vision and visual attention. Springer: Current developmental report: (14):267 -280. Retrieved on July $8^{\text {th }} 2014$ at

http: \w.w.w.ncbi.nlm.nih.gov.pubmed.

7.20amfrom

68. Tambo, L.I. (2003). Principles and methods of teaching: Applicable to Cameroon Schools. Buea: Anucam.

69. Tchombe, T.M.S (2013).Perspectives at in indigenous Africa and Western education and Learning, in

70. Tchombe, T.M. S.,Nsamenang, A.B,Keller and Fulop,M(2013)Editors

Psychology.An Africentric perspectives. Limbe:Design House.

71. Tchombe, T.M.S. (2014). Psychological Parameters in Teaching. Yaounde: Presses Universairesd' Afrique.

72. Thibault, M. and Walbert, D.(2007).Reading images: An introduction to visual literacy. Retrieved on April $12^{\text {th }} 2015$ at $1.20 \mathrm{pm}$ from www.learn.ne.org $\backslash i p \backslash$ pages $\backslash 675$.

73. Torgesen, J., Houston, D., Rissman, L. And Kasanonh, K. (2007). Teaching all students to read in elementary schools. A guide for principals. Portsmouth, NH: RMC. Research corporation, centre on instruction. Retrieved on July $27^{\text {th }} 2014$ at 10.10amfrom www. Centre on instruction.org. (IEJEE).

74. UNESCO (2005).Guidelines for inclusion. Ensuring Access to Education for All. Paris: UNESCO.
75. UNESCO (2007). Advocacy kid for promoting multilingual education/ Including the Excluded. Paris: UNESCO

76. UNESCO(2008). Education in Cameroon statistics on school enrolment, Paris: UNESCO.

77. Van-Hiele, P. (2012). Mind map for Van Hiele model of geometric thought. Elearning. Retrieved on October $3^{\text {rd }} 2014$ at 10.20am from wwwgogeometry.com $\backslash$ mindmap $\backslash$ van/hielle/geome try-level.html.

78. Vygotsky, L.(1978). Simple Psychology. Retrieved on June $17^{\text {th }} 2014$ at 9.20 amfrom www.simple psychology org/vygotsky.htm/.

79. Vygotsky, L. (1920). Social cognitive theory of development. Retrieved from www.simplepsychology.org lvygotsky.html on the 17/6/2014.

80. Wagner,C. (2015) Reading Activities. Retrieved on July $8^{\text {th }} 2014$ at 7.20amfrom www.triumphantlearning com/15-readingactivities

81. Warren, H., Wheelock, N. and Silvaroli, J.(2010).Visible language: An independent scholar journal Retrieved on July $11^{\text {th }} 2014$ at 8.50 amfrom http: \|Visible language journal.com.

82. Wood rome, S.E. and Kathy, E.J.(2008). The role of visual discrimination in the learning to read process. An interdisciplinary journal, v22n2p117131Retrieved on April $14^{\text {th }} 2014$ at 7.20amhttp://www.researchgate.net/publicationin-the-learning to read process.

83. Wood rome, S.E. and Kathy, E.J.(2007). Reading and Writing: An Interdisciplinary Journal, V22n2 P117-131. Retrieved on April $15^{\text {th }} 2014$ at 7.20amfromeric,ed.gov $\backslash$ ?idequalll E1825342.

84. Wood rome, S. E. and Kethy E. J. (2009). Visual discrimination: school sparks kinder garden readiness. Retrieved on July $8^{\text {th }} 2014$ at 7.20amfromhttp://visible language journal. com.web/abstract labs.

85. World Bank Report (2014). Cameroon Economic Update: "Revisiting the Sources of Growth" The Quality of Basic Education, 7.

86. Yuh, E. (2014).AJOSE: Supporting the classroom teacher to understand and teach diverse learners in the classroom. African Journal of Special Education, (AJOSE). (2), 81 01, .1-8. 